\title{
THE AEROSOLS, RADIATION AND CLOUDS IN SOUTHERN AFRICA FIELD CAMPAIGN IN NAMIBIA Overview, Illustrative Observations, and Way Forward
}

\author{
Paola Formenti, Barbara D’Anna, Cyrille Flamant, Marc Mallet, Stuart John Piketh, \\ Kerstin Schepanski, Fabien Waquet, Frédérique Auriol, Gerard Brogniez, Frédéric Burnet, \\ Jean-Pierre Chaboureau, Aurélien Chauvigné, Patrick Chazette, Cyrielle Denjean, Karine Desboeufs, \\ Jean-François Doussin, Nellie Elguindi, Stefanie Feuerstein, Marco Gaetani, Chiara Giorio, \\ Danitza Klopper, Marc Daniel Mallet, Pierre Nabat, Anne Monod, Fabien Solmon, Andreas Namwoonde, \\ Chibo Chikwililwa, Roland Mushi, Ellsworth Judd Welton, and Brent Holben
}

New ground-based and aircraft measurements in Namibia will improve the understanding of the role of aerosols on the regional climate of the southeast Atlantic Ocean offshore southern Africa.

THE WEST COAST OF SOUTHERN AFRICA: A CLIMATICALLY RELEVANT AND SENSITIVE REGION. The west coast of southern Africa (WCSA) is a key region of Earth's system. It is characterized by a semipermanent and extensive stratocumulus (Sc) cloud deck formed under a strong subsidence inversion of the anticyclonic circulation above the cool waters of the oceanic upwelling zone (Tyson and Preston-Whyte 2000).

Low-level Sc clouds increase the net amount of outgoing radiation at the top of the atmosphere (TOA), inducing the most negative radiative effect of any cloud regime (Boucher et al. 2013). The properties of the South Atlantic Sc strongly affect the temperature gradients of the Atlantic Ocean's surface waters and large-scale energy balance, which could influence the position of the intertropical convergence zone (ITCZ), large-scale atmospheric features such as the West African and Asian monsoons, and precipitations as far as in the Amazonian region of Brazil (Jones et al. 2009; Jones and Haywood 2012; Roehrig et al. 2013). The WCSA is also known for the northern Benguela upwelling system (nBUS), located off the west coast of Namibia, south of the Angola-Benguela front $\left(\sim 17^{\circ} \mathrm{S}\right)$ and north of the strong upwelling cell at Lüderitz $\left(26^{\circ} \mathrm{S}\right)$. This gives rise to a complex and highly variable ecosystem (Shannon and Nelson 1996), characterized by perennial coastal and open-ocean upwelling that is mostly wind driven but modulated by several atmospheric and oceanographic processes (Wasmund et al. 2016). As a consequence, the nBUS is one of the most productive marine ecosystems in the world, promoting high primary plankton production and fish populations (Jarre et al. 2015; Louw et al. 2016).

Future climate projections point to southern Africa as a region where severe warming will occur (Intergovernmental Panel on Climate Change 2013). 
Under the RCP8.5 emission scenario of continually increasing $\mathrm{CO}_{2}$ emissions throughout the twentyfirst century, South Africa, Namibia, and Botswana should experience temperature increases of up to $1.5^{\circ}-2.5^{\circ} \mathrm{C}$, particularly during the September-November season (Maúre et al. 2018). A larger fraction of land should face robust decreases in precipitation from between 0.2 and $0.4 \mathrm{~mm} \mathrm{day}^{-1}$ (around 10\%$20 \%$ of the climatological values). These decreases are expected to be accompanied by increases in the number of consecutive dry days and decreases in consecutive wet days over the region. Furthermore the frequency of development of coastal fog could be affected (Haensler et al. 2011), which is the major source of water for the endemic flora and fauna and for human settlements in the arid Namibian ecosystem (Seely et al. 1977; Seely and Henschel 1998; Olivier 1995). These projected changes imply significant potential risks to agricultural and economic productivity, human and ecological systems, health, and water resources (Lennard et al. 2018; Maúre et al. 2018).

The projected regional climate change would also affect the strength and the dynamics of the nBUS (Bakun et al. 2010), the oceanic primary production, and availability of livestock and fish in the area, which is a major resource for the local economies (Jarre et al. 2015). Such changes also could lead to the insurgence of hypoxic conditions and phytoplankton breakdown affecting the emissions of toxic hydrogen sulfide and greenhouse gases (Carr 2002), and ultimately the sequestration of carbon dioxide (Keeling et al. 2010).

AFFILIATIONS: FormentI, Desboeufs, AND DousSin—LISA, UMR CNRS 7583, Université Paris-Est-Créteil, Université de Paris, Institut Pierre Simon Laplace, Créteil, France; D'ANNA-IRCELYON, UMR CNRS 5256, Université Lyon I, Villeurbanne, and Aix Marseille Université, CNRS 7376, LCE, Marseille, France; FLAMANT-LATMOS, UMR CNRS 8190, Sorbonne Université, Université Paris-Saclay, Institut Pierre Simon Laplace, Paris, France; M. Mallet, Burnet, Denjean, and Nabat-CNRM, Université de Toulouse, Météo-France, CNRS, Toulouse, France; PIKETH AND KLOPPER-North-West University, Potchefstroom, South Africa; SCHEPANSKI AND FeUERSTEIN-TROPOS, Leipzig, Germany; WaQUet, Auriol, Brogniez, and Chauvigné-LOA, UMR CNRS 8518, Université de Lille, Lille, France; Chaboureau, Elguindi, AND SOLmon-LA, Université de Toulouse, CNRS, UPS, Toulouse, France; CHAZETTELSCE, CEA-CNRS-UVSQ, Gif-sur-Yvette, France; GAETANI-LISA, UMR CNRS 7583, Université Paris Est Créteil et Université Paris Diderot, Institut Pierre Simon Laplace, Créteil, and LATMOS, UMR CNRS 8190, Sorbonne Université, Université Paris-Saclay, Institut Pierre Simon Laplace, Paris, France; GIORIO-Dipartimento di Scienze Chimiche, Universital degli Studi di Padova, Padua, Italy;

\section{THE WEST COAST OF SOUTHERN AF-} RICA: A PUZZLING CLIMATE AND THE ROLE OF AEROSOLS. Understanding and predicting the regional climate of the WCSA is not without challenges. Global climate models (GCMs) overestimate the surface temperature over the eastern tropical oceans (Zheng et al. 2011; Flato et al. 2013). This long-standing bias is attributed to errors in the representation of wind fields, clouds, oceanic upwelling, and more recently, surface evaporation and latent heat flux (Hourdin et al. 2015; Gainusa-Bogdan et al. 2018). The recent sensitivity experiments of GainusaBogdan et al. (2018) show that an improved understanding of the air-sea coupling succeeds in reducing the warm bias of the sea surface temperature (SST) globally, but not in the WCSA. The poor understanding of the processes controlling the energy budget at the air-sea interface persists.

GCMs also have difficulties in representing the energy balance at the TOA over the WCSA. In the presence of biomass-burning aerosols (BBA), the seasonal estimate of the direct radiative effect (DRE) by GCMs diverge by several watts per square meter (Myhre et al. 2013).

The WCSA is a crossroad of large quantities of natural and anthropogenic aerosols of distant and local origins (biogenic, anthropogenic, biomass burning, sea salt, and mineral dust) from continental and marine sources, with significant differences in terms of physicochemical and optical properties, water affinity, and height of transport.

Southern Africa is the transport region of major global biomass-burning sources in central Africa

M. D. Mallet-LISA, UMR CNRS 7583, Université Paris Est Créteil et Université Paris Diderot, Institut Pierre Simon Laplace, Créteil, and IRCELYON, UMR CNRS 5256, Université Lyon I, Villeurbanne, France; MONOD-Aix Marseille Université, CNRS 7376, LCE, Marseille, France; NAmWoONDE AND CHIKWILILWA-Sam Nujoma Marine and Coastal Resources Research Centre, University of Namibia, Henties Bay, Namibia; MusHI-Gobabeb Research and Training Centre, Walvis Bay, Namibia; WeLton AND HolbeN-NASA Goddard Space Flight Center, Greenbelt, Maryland CORRESPONDING AUTHOR: Paola Formenti, paola.formenti@lisa.u-pec.fr

The abstract for this article can be found in this issue, following the table of contents.

DOI:10.II75/BAMS-D-17-0278.I

A supplement to this article is available online (I0.I175/BAMS-D-17-0278.2)

In final form 19 February 2019

(02019 American Meteorological Society

For information regarding reuse of this content and general copyright information, consult the AMS Copyright Policy. 


\begin{tabular}{|c|c|c|c|c|}
\hline $\begin{array}{l}\text { Campaign } \\
\text { acronym }\end{array}$ & Time span & Region & Objective/science focus & $\begin{array}{l}\text { Overview or } \\
\text { planning papers }\end{array}$ \\
\hline SAFARI-1992 & Aug-Sep 1992 & South Africa & $\begin{array}{l}\text { Characterize biomass- } \\
\text { burning aerosols }\end{array}$ & Lindesay et al. (1996) \\
\hline SAFARI 2000 & Aug-Sep 2000 & $\begin{array}{l}\text { South Africa and } \\
\text { Namibia }\end{array}$ & $\begin{array}{l}\text { Characterize biomass- } \\
\text { burning aerosols }\end{array}$ & $\begin{array}{l}\text { Swap et al. (2003), } \\
\text { Haywood et al. (2003) }\end{array}$ \\
\hline NaFoLiCA & Sep 2017 & Namibia & $\begin{array}{l}\text { Temporal and spatial patterns } \\
\text { of fog in the Namib region }\end{array}$ & Andersen and Cermak (2018) \\
\hline AEROCLO-sA & Aug-Sep 2017 & Namibia & $\begin{array}{l}\text { Characterize MBL and } \\
\text { biomass-burning aerosols }\end{array}$ & This study \\
\hline ORACLES & $\begin{array}{l}\text { Aug-Sep 2016, } \\
\text { Jul-Aug 2017, } \\
\text { Sep-Oct } 2018\end{array}$ & $\begin{array}{l}\text { Namibia, } \\
\text { Sao Tomé, } \\
\text { Sao Tomé }\end{array}$ & $\begin{array}{l}\text { Characterize biomass- } \\
\text { burning aerosols }\end{array}$ & Zuidema et al. (2016) \\
\hline CLARIFY & Aug-Sep 2017 & $\begin{array}{l}\text { Atlantic Ocean around } \\
\text { Ascension Island }\end{array}$ & $\begin{array}{l}\text { Characterize biomass- } \\
\text { burning aerosols }\end{array}$ & Zuidema et al. (2016) \\
\hline LASIC & Jul 2016-Oct 2017 & Ascension Island & $\begin{array}{l}\text { Characterize biomass- } \\
\text { burning aerosols }\end{array}$ & Zuidema et al. (2016) \\
\hline
\end{tabular}

(van der Werf et al. 2010). Forest fires occurring in the austral dry season (August-October) contribute to the regional aerosol load with thick and widespread smoke layers of high optical density and are generally lofted above the Sc (Lindesay et al. 1996; Swap et al. 2003).

The annual emissions of mineral dust from southern Africa are around 2,300 Mg (approximately 5\% of the global annual emissions) and are on the same order of magnitude of those from major recognized sources in Arabia and the deserts of East Asia (Ginoux et al. 2012). Namibia is the largest source region of mineral dust in southern Africa. Here, Vickery et al. (2013) identified approximately 70 emitting point sources (mostly ephemeral dry riverbeds along the Namibian coastline) as well as the major source of the Etosha Pan, Namibia. The deposition of nutrients from mineral dust contribute significantly to the coastal oceanic primary production (Dansie et al. 2017) and the long-range transport of mineral dust from Namibia to the central tropical South Atlantic is also documented (Swap et al. 1996).

Anthropogenic aerosols are expected due to the anticyclonic episodic long-range transport of industrial aerosols from South Africa (Formenti et al. 1999; Piketh et al. 1999), one of the largest industrialized economies in the Southern Hemisphere, and from increasing maritime ship traffic (Tournadre 2014; Johansson et al. 2017). Finally, deep-water and coastal upwelling and wind friction on the sea surface emit marine biogenic aerosols and sea salts (Andreae et al. 1995). Satellite and in situ observations document the extraordinary primary activity of the nBUS and the occurrence of extended and persistent blooms of phytoplankton offshore Namibia (Verheye et al. 2016). The early phase of the phytoplankton life cycle is associated with high concentrations of dimethylsulfide (DMS) in both water and air (Andreae et al. 1995; Bates et al. 2001). The senescence of phytoplankton is accompanied by intense emissions of other sulfur species [e.g., hydrogen sulfide $\left(\mathrm{H}_{2} \mathrm{~S}\right)$ ] and is, at times, visible in water color images for several weeks (Weeks et al. 2004; Ohde and Dadou 2018). The anaerobic decomposition of sediments can create a "diatom mud" rich in organic matter along the Namibian coast (Borchers et al. 2005).

In the 1990s, large-scale initiatives, such the Southern African Fire-Atmosphere Research Initiative (SAFARI; Andreae et al. 1996) and the Southern African Regional Science Initiative in 2000 (SAFARI 2000; Swap et al. 2003), targeted the representation of the seasonal BBA and their interactions with radiation and clouds. These observational efforts provided, amongst many other results, the first regionally and seasonally averaged evaluation of the single scattering albedo (SSA) for African BBA at $550 \mathrm{~nm}(0.85 \pm 0.02$; Leahy et al. 2007). These observations were important for improving climate models but were limited in describing the expected spectral dependence and intensity of aerosol absorption (Lewis et al. 2008; Liu et al. 2014; Bluvshtein et al. 2017; Radney et al. 2017; Saturno et al. 2018) and its evolution during atmospheric transport (Abel et al. 2003; Formenti et al. 2003; Kirchstetter et al. 2003; Andreae and Gelencsér 2006; Deboudt et al. 2010). SAFARI 2000 also provided the first observational-based evidence that absorbing BBA above clouds would produce areas of positive forcing (Keil and Haywood 2003). The 
need for constraining the vertical distributions of the aerosol and cloud layers, and their microphysical and radiative interactions has stemmed as a recommendation from those pioneering studies (Hobbs 2003; Magi et al. 2003; Ross et al. 2003).

\section{SCIENTIFIC OBJECTIVES OF THE AEROCLO-SA PROJECT. The persisting dif-} ficulties of GCMs in representing the aerosol DRE in the region (Myhre et al.2013) have motivated a number of new large-scale experiments (Table 1). Among those is Aerosols, Radiation and Clouds in southern Africa (AEROCLO-sA), a multiagency program initiated by France. It consists of German, Italian, Greek, South African, and Namibian scientists (full list of contributors in Table ES1 in the online supplemental material; https://doi.org/I0.I I75/BAMS-D-BAMS-D-17-0278.2) aiming to characterize the regional aerosols for an observational-validated evaluation of their radiative effects over the WCSA.

AEROCLO-sA addresses the following questions: What is the chemical composition of mineral dust, biomass-burning, and marine aerosols emitted or transported in the WCSA? What is their state of mixing? What are their spectral absorption properties? What is their hygroscopicity? What is the vertical distribution of aerosols and clouds over land and over ocean? Is there entrainment of biomass burning in the marine Sc clouds? Is there an anthropogenic signature in the marine boundary layer (MBL) aerosols (e.g., from ships)? What are the mechanisms of dust uplift and how far is it transported offshore? What is the role of aerosols in the development of coastal fog?

Thanks to the persistence of the Sc clouds in the region, AEROCLO-sA is also a unique opportunity to evaluate the development of advanced spaceborne remote sensing of aerosols and clouds. As part of its major objectives, AEROCLO-sA also supports the development of the novel multispectral retrieval algorithms planned by Centre National d'Études Spatiales (CNES) in preparation for the future Multiviewing, Multi-channel, Multi-polarization Imager (3MI) and Infrared Atmospheric Sounding Interferometer-New Generation (IASI-NG) instruments on the second-generation Meteorological Operational satellites (MetOp-SG), with a planned launch in 2021.

This paper provides an overview of the observational and modeling strategies of the project. It describes the ground-based and airborne field campaign that was conducted over Namibia in August-September 2017, and presents selected first results illustrating the capability of the collected data to advance the science objectives of the project, and the prediction of climate in the region. Finally, the paper provides details of the data distribution and communication plans to foster collaboration beyond the boundaries of the primary consortium.

\section{THE AEROCLO-SA OBSERVATIONAL AND MODELING STRATEGY. The AERO-} CLO-sA project is centered on a field campaign that was conducted in Namibia in August and September 2017. The ground-based detachment took place from 23 August to 12 September 2017 at the SANUMARC Research Centre of the University of Namibia in Henties Bay $\left(22^{\circ} 6^{\prime} \mathrm{S}, 14^{\circ} 30^{\prime} \mathrm{E} ; 20 \mathrm{~m} \mathrm{MSL}\right)$. Since 2011, the center has hosted the Henties Bay Aerosol Observatory (HBAO; www.hbao.cnrs.fr), part of the Aerosol Robotic Network (AERONET) global sun photometer network and recently established as a regional station of the World Meteorological Organization (WMO)/Global Atmosphere Watch (GAW) program (Formenti et al. 2018). During the campaign, HBAO was augmented by the groundbased mobile laboratory Portable Gas and Aerosol Sampling Units (PEGASUS) of the Laboratoire Interuniversitaire des Système Atmosphériques (LISA; Fig. ES1), equipped with a full suite of aerosols and gas-phase instrumentation, fog sizers and collectors, radiosondes, and tethered balloons (Table ES2).

The airborne campaign was conducted with the French Falcon 20 environmental research aircraft (Fig. ES2) operated by the Service des Avions Français Instrumentés pour la Recherche en Environnement (SAFIRE), and was deployed from the Walvis Bay International Airport from 5 to 12 September 2017. The aircraft was equipped with active and passive remote sensors as well as in situ probes (Table ES3) to measure aerosol optical and radiative properties over land and over maritime Sc clouds. It performed 10 research flights ( $\sim 30$ flight hours; Table ES4) over northern Namibia, focusing on mineral dust emission and BBA, and their near-range transport over the marine clouds of the Atlantic Ocean (Fig. ES3).

The modeling strategy is constructed around emission and/or transport and regional climate models at various resolutions (see details in the online supplement). To illustrate mesoscale features such as the emission and transport of aerosols from point sources, their dispersion in the boundary layer and their intrusion into clouds, real-time high-resolution forecasts and analysis of clouds, dust, and biomassburning events were made with the French limited area mesoscale model Meso-NH (Lac et al. 2018). In 
(a)

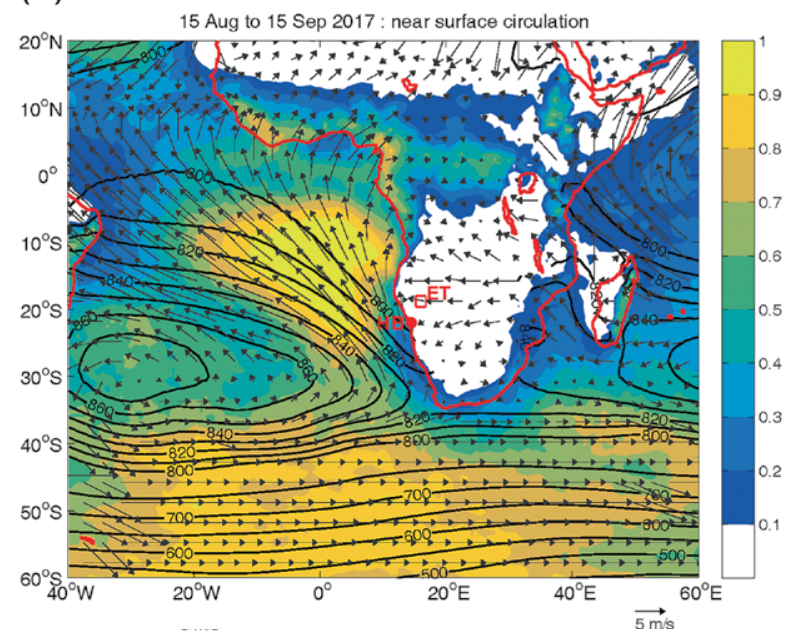

(c)

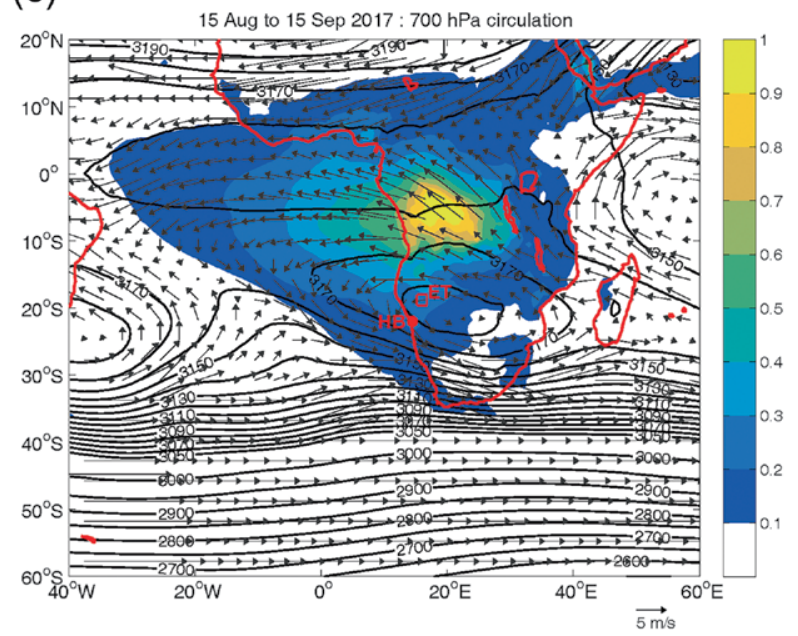

addition, the atmosphere-aerosol model Consortium for Small-Scale Modeling Multiscale Chemistry Aerosol Transport Model (COSMO-MUSCAT; Schepanski et al. 2016) is being used to a) improve the representation of southern African dust source in mesoscale models and b) examine atmospheric drivers initiating dust entrainment and consequent dust transport pathways.

Regional climate modeling (RCM) exercises are being conducted with two models: Aire Limitée Adaptation Dynamique Développement International Climate (ALADIN-Climate; Nabat et al. 2015) and Regional Climate Model (RegCM; Giorgi et al. 2012). Both models incorporate "online" mineral dust and BBA schemes that will be characterized and improved with the campaign observations. The RCM activity will quantify the direct and semidirect radiative effect of the mixed aerosols in the Sc area and evaluate whether the inclusion of aerosol radiative perturbations modify the microphysical and/or optical properties of Sc clouds. (b)

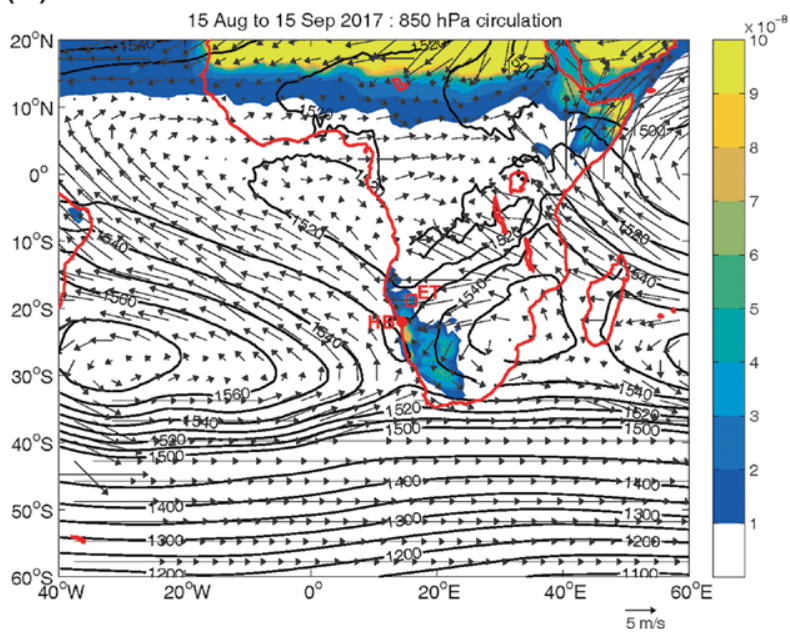

FIG. I. (a) Low-level cloud-cover fraction (shading), geopotential height at $925 \mathrm{hPa}$ (contours; $\mathrm{m}$ ), and $10-\mathrm{m}$ wind (arrows) averaged between 15 Aug and 15 Sep 2017. (b) Dust aerosol mixing ratio at $10 \mathrm{~m}$ (shading; $\mathrm{kg} \mathrm{kg}^{-1}$ ), geopotential height at $850 \mathrm{hPa}$ (contours; $\mathrm{m}$ ), and wind at $850 \mathrm{hPa}$ (arrows) averaged for the same period. (c) Organic matter AOD at $550 \mathrm{~nm}$ (shading), geopotential height at $700 \mathrm{hPa}$ (contours; $\mathrm{m}$ ), and wind at $700 \mathrm{hPa}$ (arrows) averaged for the same period. Data are from CAMS near-real-time forecast (http://apps.ecmwf.int/datasets/data/cams-nrealtime/).

\section{SYNOPTIC METEOROLOGY, AEROSOL, AND CLOUD ACTIVITY DURING THE} CAMPAIGN. The average meteorological conditions during the campaign (from 15 August to 15 September 2017) are shown in Fig. 1 [based on the European Centre for Medium-Range Weather Forecasts Copernicus Atmosphere Monitoring Service (ECMWF CAMS) near-real-time forecasts]. These observed conditions are similar to the climatology of the period obtained from ECMWF interim reanalysis (ERA-Interim; Fig. ES4) for the period 1979-2016, with the exception of two warm anomalies in September (not shown).

From 15 August to 15 September 2017, the nearsurface atmospheric circulation was characterized by two semipermanent high pressure systems in the Atlantic and Indian Oceans (Fig. 1a). This circulation pattern led to marked easterly winds over the southern African plateau. Over the ocean and along the WCSA, the near-surface atmospheric circulation at the foothill of the plateau was controlled by the 
Atlantic anticyclone. The resulting wind pattern led to the activation of mineral dust sources in southern Namibia and South Africa, while little dust emission was observed north of Henties Bay, and over the Kalahari Desert and the Etosha Pan (Fig. 1b). The observed overall circulation pattern is similar to the climatology for this period, although with the Atlantic anticyclone shifted to the southwest of its mean position, weaker winds along the WCSA, and a low pressure anomaly southeast of Madagascar (Figs. ES4a,b). Accordingly, dust emission from Etosha Pan and coastal sources were weaker than generally seen during this period of the year (from CAMS data for 2013-16), with the exception of one episode along the coast on 18 August (Fig. 2a) and two episodes over Etosha on 18 August and 3-5 September (Fig. 2b).

The lower-tropospheric circulation at $850 \mathrm{hPa}$ during the campaign (Fig. 1b) was similar to the near-surface pattern (Fig. 1a). No low-level clouds were forecasted (nor observed) over the southern

(a)

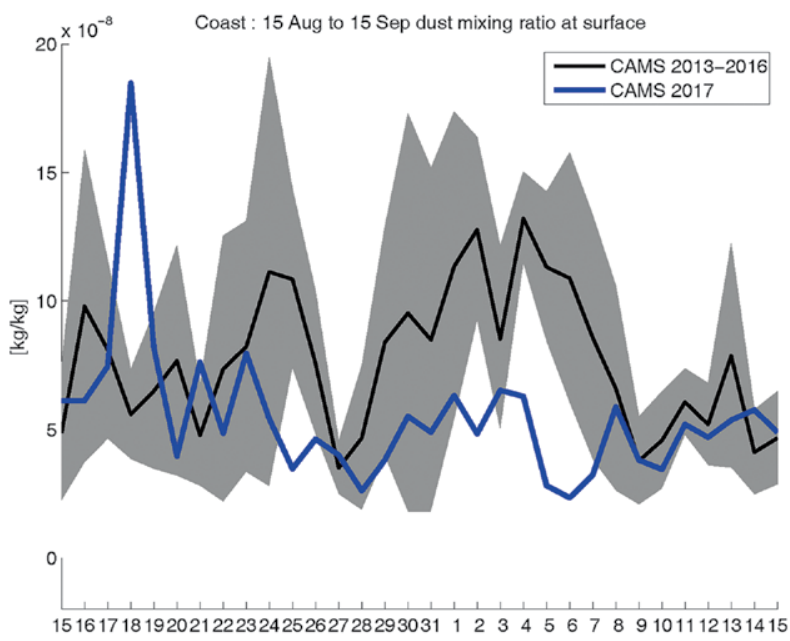

(c)

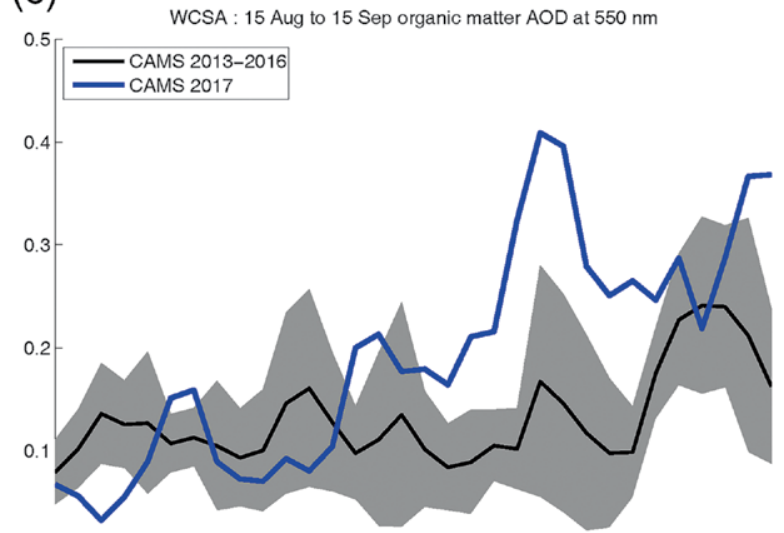

0

151617181920212223242526272829303112234567899101112131415
Africa plateau during the campaign (Fig. 1a), while the low-level cloud fraction over the South Atlantic Ocean increased with the distance from the WCSA, in accordance with the climatology (Fig. ES4c). It was on the order of $20 \%-40 \%$ along the Namibian coast north of Henties Bay (Fig. 1a). The low-level cloud cover south of Henties Bay was on the order of $10 \%-30 \%$ (Fig. 1a), that is, significantly lower than the climatological mean (see Fig. ES4d).

In the midtroposphere, a continental anticyclone was dominant over the plateau of central southern Africa. It was associated with strong easterly flow to the north [the southern African easterly jet (AEJ-S); Adebiyi and Zuidema 2016] as well as strong westerly flow over the southern tip of South Africa (Fig. 1c). This circulation pattern does not show significant modifications compared to the climatology, with the exception of the high pressure anomaly in the southwestern Atlantic (Figs. ES4e,f), which was the main circulation feature characterizing the 15 August-15

(b)

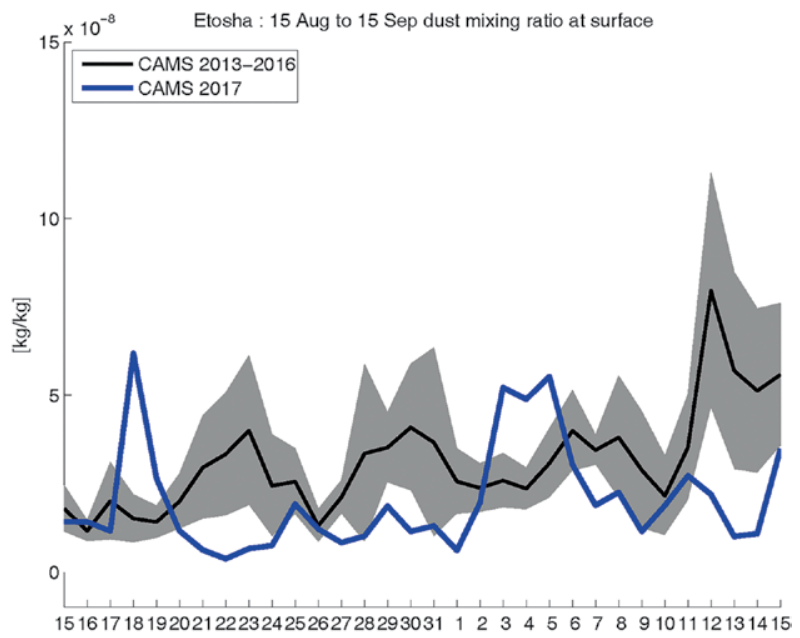

FIG. 2. (a) CAMS-derived dust mixing ratio at $10 \mathrm{~m}$ $\left(\mathrm{kg} \mathrm{kg}^{-1}\right)$ averaged from sources along the WCSA (see domain in Fig. ES5), from 15 Aug to 15 Sep for the 2017 time series (blue line) and the 2013-16 mean (black line). The daily variability for the 2013-16 period is indicated by the gray shading, which represents the 25th-75th percentile range. (b) As in (a), but for dust mixing ratio from Etosha (see domain in Fig. ES4). (c) As in (a), but for organic matter AOD. Data are from CAMS near-real-time forecast (http://apps.ecmwf.int/datasets/data/cams-nrealtime/). 

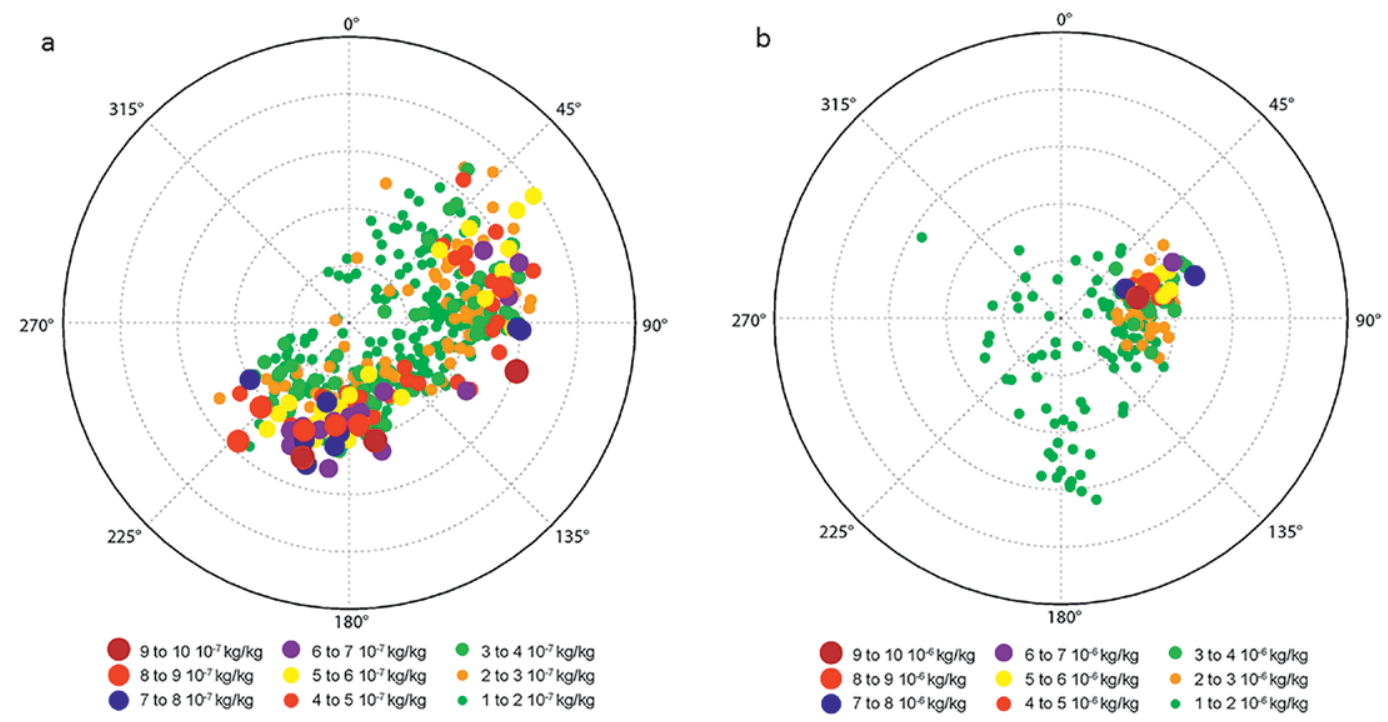

FIG. 3. Polar plots of CAMS-derived mixing ratios (color; $\mathbf{k g ~ k g}^{-1}$ ) for dust particle sizes of $0.03-20 \mu \mathrm{m}$ for $\mathbf{~} 5$ Aug-15 Sep for 2012-17 as a function of wind speed (circles) and wind direction for (a) Etosha and (b) WCSA. The domains over which the mixing ratios are extracted are shown in Fig. ES5. Circles range from 0 to $10 \mathrm{~m} \mathrm{~s}{ }^{-1}$, with circles every $2 \mathrm{~m} \mathrm{~s}^{-1}$.

September 2017 period. Organic aerosol associated with the development of dry-season wildfires in the vegetated African tropics are lifted to the midtroposphere, transported across the ocean by easterly winds, and recirculated to the south toward Namibia and South Africa by the continental anticyclonic circulation, dominating the aerosol optical depth (AOD) in the region (Fig. 1C). While being transported westward by midtropospheric winds, BBA were advected over the southeast Atlantic Sc cloud deck (Fig. 1c). Above the WCSA, organic matter AOD was within the climatological variability in the last two weeks of August, while being anomalously high during the first two weeks of September (Fig. 2c).

ILLUSTRATIVE CASE STUDIES. In this section we illustrate case studies provided by the first integration of the ground-based, airborne, and RCM simulations.

Emission and transport of mineral dust. Little is known about the mechanisms and occurrences of emission of mineral dust from the Namibia sources, as well as about their vertical distribution during transport. To fill these gaps, AEROCLO-sA has a double objective: i) study the mechanisms responsible for desert aerosol uplift over identified emission hotspots, their dependence on surface conditions, weather, heterogeneities of surface albedo, and topography; and ii) construct the first multiyear estimate of mineral dust emission from Namibia and evaluate its seasonal and annual variability.
For the period 2012-17 between 15 August and 15 September, dust mixing ratios at $10 \mathrm{~m}$ derived from CAMS illustrate the variety of meteorological conditions likely to activate the Etosha Pan and coastal sources during the campaign (Fig. 3 ). The largest mixing ratio values over Etosha (see domain in Fig. ES5) are associated with moderate easterly winds as well as with southerly winds (between 4 and $6 \mathrm{~m} \mathrm{~s}^{-1}$; Fig. 3a). CAMS-derived dust mixing ratios over Etosha are rarely associated with northwesterly winds (i.e., coming from directions between $225^{\circ}$ and $45^{\circ}$ ). In the coastal region, the largest dust loads at $10 \mathrm{~m}$ (see domain in Fig. ES5) are associated with moderate east-northeasterly onshore winds (between 2 and $5 \mathrm{~m} \mathrm{~s}^{-1}$; Fig. 3b). Southerly winds appear to be less efficient in producing large dust loads, most likely because of the orientation of the dry riverbeds, which is mainly running east-west. It is also worth noting that small dust loads are associated with winds from nearly all directions, including northwesterly winds associated with disturbances such as coastal lows.

The meteorological situation and the dynamical processes that led to the intense emission episode over Etosha during the campaign (see Fig. 2b) are investigated further here as a specific case study. On 5 September, a westerly disturbance and cold front approached and passed over the southern portion of the subcontinent (Fig. 4). The near-surface circulation pattern associated with the Atlantic anticyclone was characterized by weak southwesterly winds along the coast (corroborated by $10-\mathrm{m}$ wind speed 


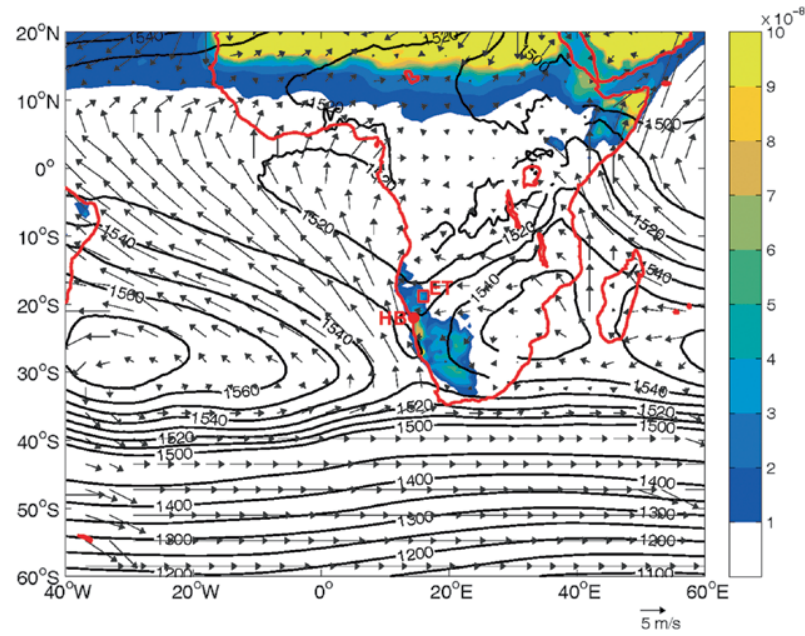

FIG. 4. Dust aerosol mixing ratio at $10 \mathrm{~m}$ (shading; $\mathrm{kg} \mathrm{kg}^{-1}$ ), geopotential height at $850 \mathrm{hPa}$ (contours; $\mathrm{m}$ ), and I0-m wind (arrows) on 5 Sep 2017.

measurements made at Henties Bay; not shown), and moderate activation of the coastal dust sources (shown in Fig. 4). The most notable feature in the near-surface circulation pattern is the proximity of the semipermanent Indian Ocean anticyclone with the eastern coast of southern Africa. This favors the penetration of a strong easterly flow over the interior of southern Africa, which in turn leads to the activation of dust sources over the continental plateau in northern Namibia (e.g., Etosha Pan; see Fig. 2b) and in South Africa.

Dust emission in the Etosha Pan region was also forecasted by the Meso- $\mathrm{NH}$ and is evident in the surface dust concentrations forecast at 0900 UTC (Fig. 5a). This episode took place at the end of a 2-day period during which the dust sources in the Etosha Pan and along the western coast of Namibia were very active (Figs. 2a,b).

In situ and remote sensing measurements during the first flight of the Falcon 20 are combined to describe the aerosol layering (Table ES4). After taking off at 0736 UTC from Walvis Bay, the Falcon 20 headed straight to Etosha to sample the early morning dust emissions (Vickery et al. 2013). Two dropsondes were launched over the pan and three downstream, with the last being released over the coastal ocean. Data from the dropsonde released at 0840 UTC over the pan revealed the presence of a developing $~ 300$-m-deep convective boundary layer (CBL) with relatively low relative humidity $(20 \%)$ and moderate north-northeast winds $\left(\sim 8 \mathrm{~m} \mathrm{~s}^{-1}\right.$; Figs. 5b,c). A strong low-level jet peaking at $17 \mathrm{~m} \mathrm{~s}^{-1}$ was observed just above the developing CBL at approximately $600 \mathrm{~m}$ above ground level (AGL). Data from the airborne lidar (Fig. 5d) show an enhanced atmospheric backscatter coefficient at $1,064 \mathrm{~nm}$ in the CBL, likely generated by dust uplifted by the near-surface winds from the downward mixing of momentum from the low-level jet after sunrise, as already observed in West Africa (e.g., Washington and Todd 2005). The dust layer over Etosha was separated from the lofted BBA by a thin layer of lower backscatter indicative of low aerosol content.

The morning dropsonde launched over the ocean close to Henties Bay (0951 UTC) revealed the presence of a sharp relative humidity transition from $80 \%$ to less than $5 \%$ at the top of the BBA layer at close to $6 \mathrm{~km}$ MSL (Fig. 6a), while over land the transition near the top of the BBA layer was almost $1 \mathrm{~km}$ deep. This either suggests stronger large-scale subsidence over the ocean than over land, as pointed out by Das et al. (2017), or more vigorous mixing. The upper part of the BBA layer (i.e., above $\sim 3 \mathrm{~km} \mathrm{MSL}$ ) was advected from the northwest while the lower part was transported from the northwest (over land; Fig. 5c) or the north (over sea; Fig. 6b). The data from the lidar (Fig. 5d) and the relative humidity profiles (Fig. 6b) indicate the stratocumulus clouds over the ocean, and an above aerosol layer (Fig. 5d) resulting from the transport of dust from the coastal deserts north of Henties Bay, and possibly from Etosha. As observed over Etosha, a clean layer separated the dust and the BBA over the ocean. The presence of dust above (and in) the Sc clouds was also simulated with Meso-NH (Fig. 6d) over Henties Bay between 1000 and 1030 UTC when the aircraft was closest to the ground-based supersite. The Meso-NH simulation indicates the absence of dust below the Sc clouds that formed during the late morning, in conjunction with weak surface winds suggested by the model simulations and confirmed by the observations in Henties Bay (Fig. 6f). The absence of dust below the low-level clouds is also corroborated by the low volume depolarization ratio measured with the groundbased lidar in Henties Bay (Fig. 6c). The dust load transported above the $\mathrm{Sc}$ from remote sources was associated with moderate AOD $(\sim 0.2-0.3)$ as modeled with Meso-NH (Fig. 6e). The data gathered in such a complex aerosol-cloud environment will serve to challenge the spaceborne aerosol retrievals over both land and ocean.

\section{IMPROVING THE REPRESENTATION OF THE PROPERTIES AND RADIATIVE EF-} FECTS OF BIOMASS-BURNING AERO-

SOLS. One of the major science objectives of AEROCLO-sA is to provide new airborne multispectral, multidirectional, and polarized passive 

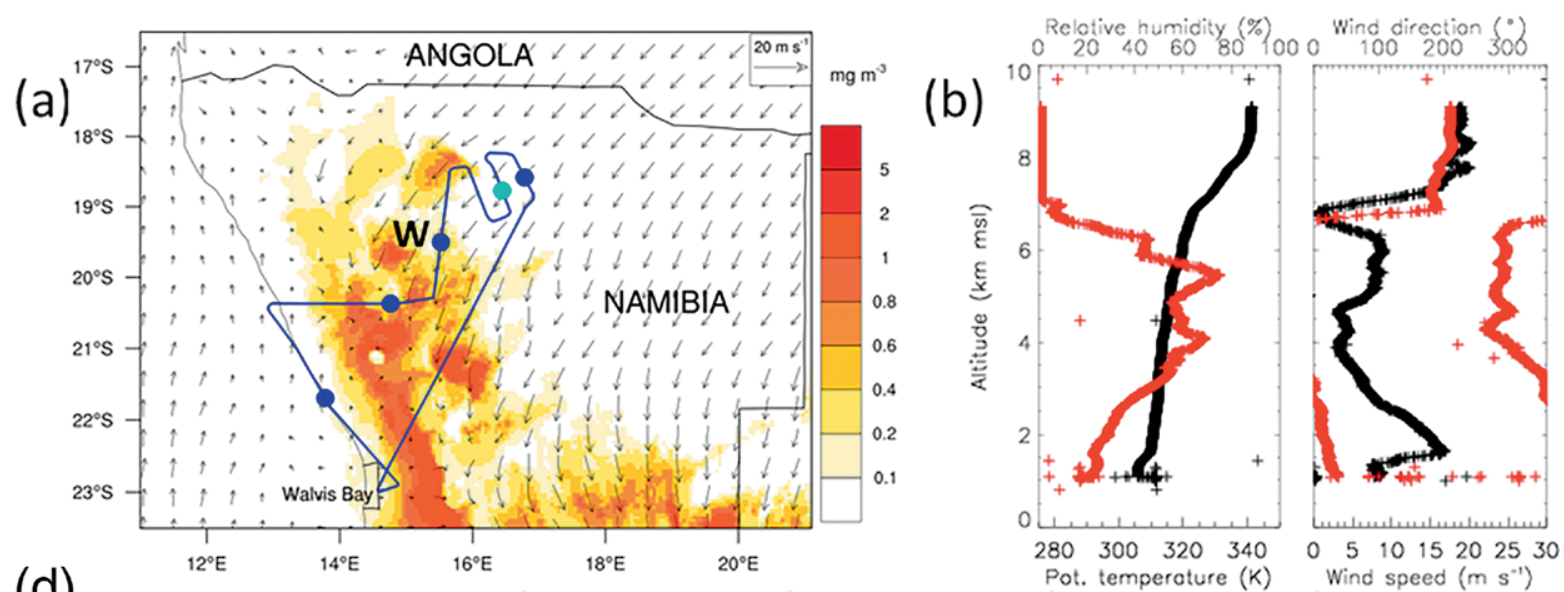

(c)

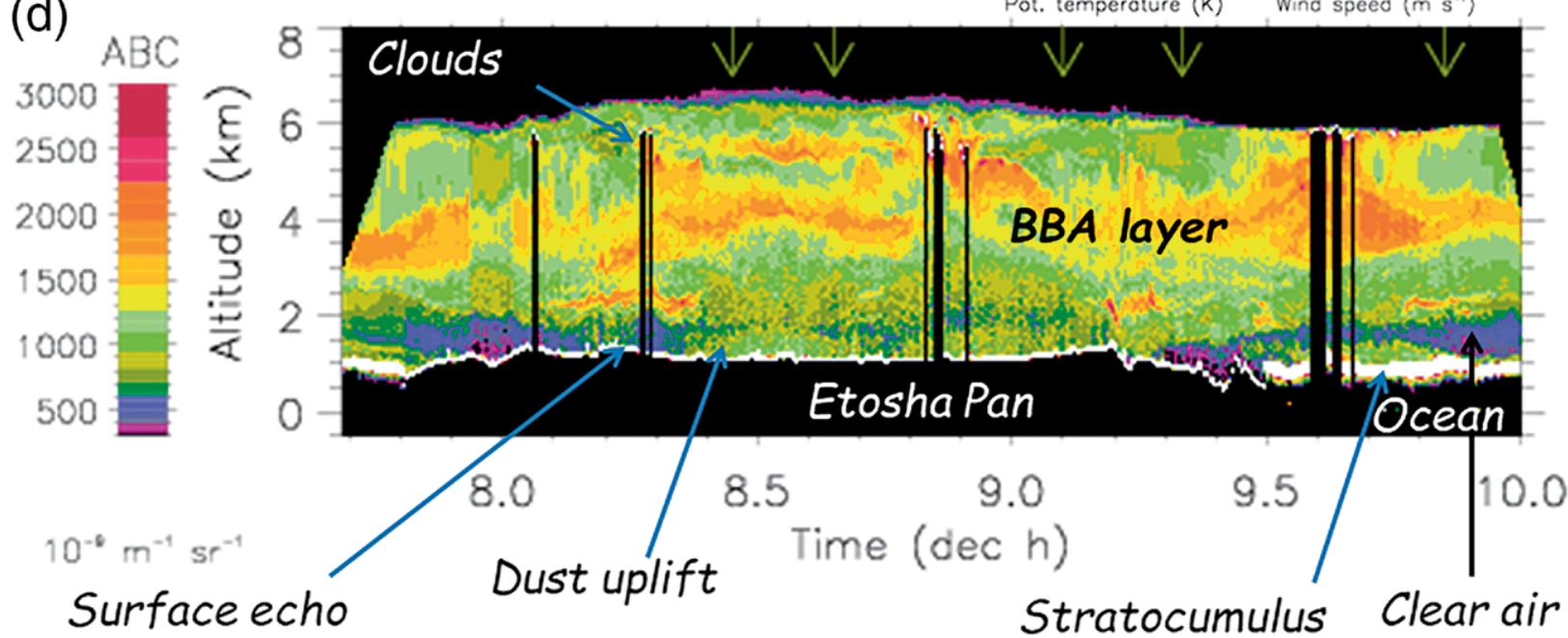

FIG. 5. (a) Flight plan of the SAFIRE Falcon 20 between 0736 and 1014 UTC 5 Sep and position of the five dropsondes during the flight (blue circles) overlaid on the surface wind and dust forecast by the Meso-NH model. The position of the MPLNET at Windpoort is indicated by its initial location (black W) and coincides with one of the dropsondes. (b) Potential temperature profiles (black) and relative humidity (red) obtained from the dropsonde released at 0840 UTC [light blue circle in (a)]. (c) As in (b), but for wind speed (black) and wind direction (red). (d) Atmospheric backscatter coefficient at $1,064 \mathrm{~nm}$ as a function of the altitude obtained under the aircraft from the LNG lidar. Arrows indicate the position of the dropsondes along the flight track.

remote sensing observations of the microphysical and optical properties and the vertical distribution of the BBA near sources, for improving their simulation in climate models and retrieval from space.

Biomass burning is the overwhelming feature of the campaign. Complex BBA layers were seen consistently over land and coast, and sampled remotely and in situ on all the research flights. Overall, 29 in situ vertical profiles of the BBA were obtained at different distances from sources.

Example observations from two specific flights are presented here. Flight 15 was conducted over land on 12 September 2017 to sample the BBA and dust over the Etosha pan. Flight 10 was performed in the morning on 7 September 2017 to study the properties of BBA above the Sc clouds over sea. Flight tracks are shown in Fig. ES3. On both days BBA was transported directly from central Africa and Angola in plumes extending over the ocean offshore Namibia and down to South Africa, as shown in Fig. ES6 by the maps of $\mathrm{AOD}$ at $500 \mathrm{~nm}$ and position of the active fires provided by MODIS/Aqua. Figure ES7 compares the vertical structure of the particle extinction coefficient at $1,064 \mathrm{~nm}$ measured by the airborne Lidar pour l'Etude des Interactions Aérosols Nuages Dynamique Rayonnement et du Cycle de l'Eau (LEANDRE) Nouvelle Génération (LNG) lidar onboard the Falcon 20 on the two days. During both flights the top of the BBA layer was around $6 \mathrm{~km}$ MSL. Over land (flight 15), it extended down to the surface and over sea (flight 10) the BBA layer was advected over a relatively "clean" air mass with low particle concentrations extending between approximately 1.5 and $3 \mathrm{~km}$. Aerosols were also observed in the MBL below. Regardless of the region 

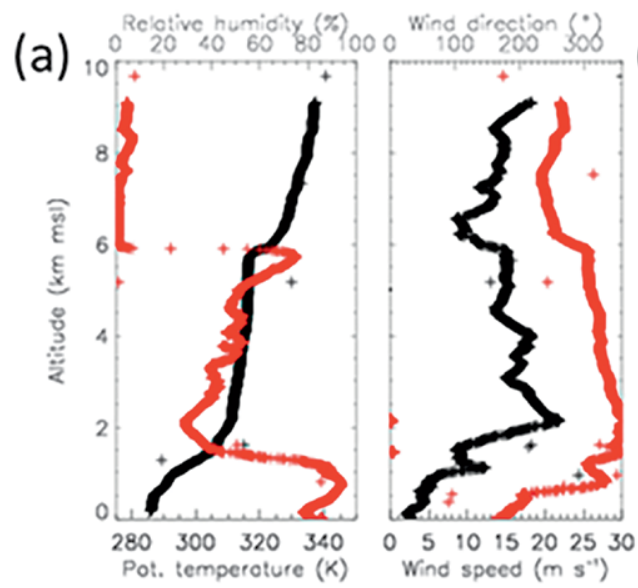

(b)

(c)

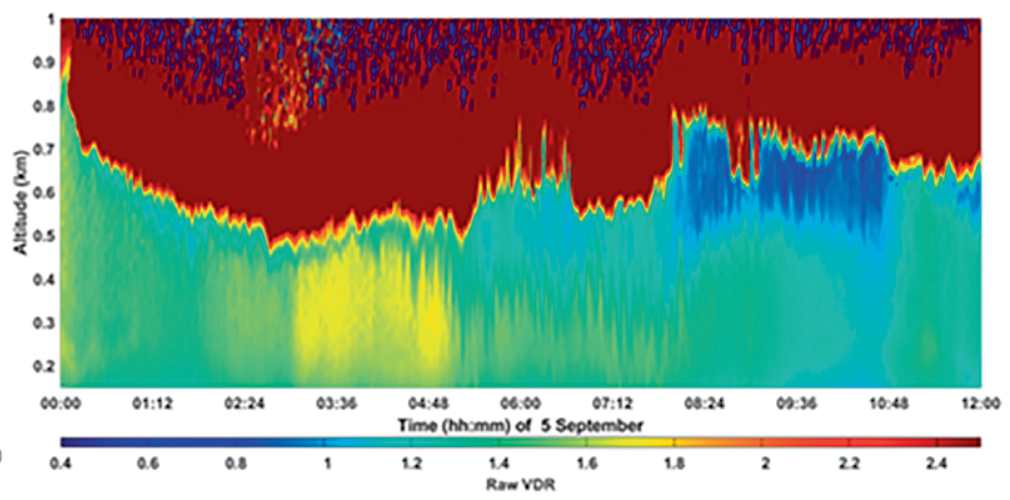

(d)

Henties_Bay

(e)

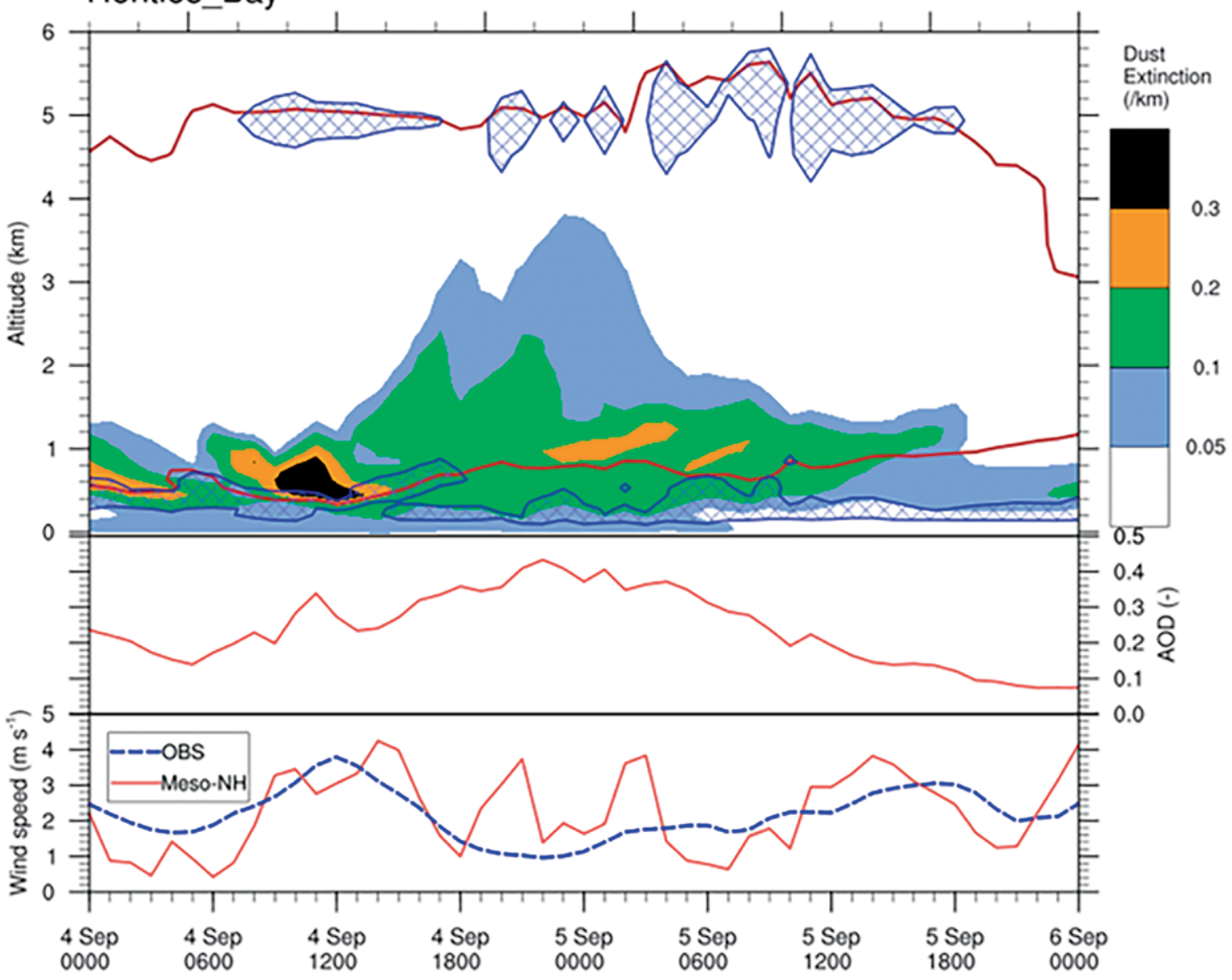

FIG. 6. (a) Potential temperature profiles (black) and relative humidity (red) obtained from the dropsonde released at 095I UTC 5 Sep 2017 (over the ocean). (b) As in (a), but for wind speed (black) and direction (red). (c) Raw volume depolarization ratio between 0000 and 1200 UTC 5 Sep derived from the ALS300 lidar in Henties Bay. Dark reddish colors indicate the presence of Sc clouds. (d) Time-height evolution of Meso-NH-simulated dust-related extinction coefficient (color) between 0000 UTC 4 Sep and 0000 UTC 6 Sep over Henties Bay. Also shown are clouds (blue-hatched closed contours) as well as the base and top of the tracer layer (black thick line), a proxy for the BBA plume. Time evolutions of (e) AOD and (f) $10-\mathrm{m}$ wind speed (dashed blue line for observations and black line for Meso-NH simulations). 
of sampling, the lofted BBA displays a complex internal structure with multiple sublayers with extinction coefficients ranging from 200 to about $500 \mathrm{Mm}^{-1}$ $\left(1 \mathrm{Mm}^{-1}=10^{-6} \mathrm{~m}^{-1}\right)$. Isolated convective clouds were observed close to the BBAlayer top suggesting that local activation of hygroscopic smoke aerosols can occur for a relative humidity around $80 \%$, as found close to the layer top height.

Figure 7 shows the vertical profiles of the AOD measured by the Photometre Léger Aéroporté pour la Surveillance des Masses d'Air (PLASMA) sun photometer above $1 \mathrm{~km}$ on both flights. Over land, the total AOD was 0.55 at $500 \mathrm{~nm}$, and decreased linearly with altitude, indicating that the BBA was well mixed at the time of sampling. Over sea, the $\mathrm{AOD}$ at $500 \mathrm{~nm}$ was even higher (0.65). The AOD was almost constant between 1 and $2 \mathrm{~km}$, where the LNG lidar data show a clean layer underlying the BBA. This indicates that the contribution of the clean layer to the total extinction is negligible and that the AOD is contributed exclusively by the lofted BBA. Contrary to the land profile, the decrease of the AOD with altitude was not steady, but different between the lower $(2-3.5 \mathrm{~km})$ and the upper part of the BBA $(3.5-5 \mathrm{~km})$, suggesting sublayering in concentrations and properties. The Ångström exponent (AE), representing the spectral dependence of the AOD, decreased with height at the lowest wavelengths, 380 and $440 \mathrm{~nm}$, but not between 440 and $870 \mathrm{~nm}$, where it remained constant with altitude. At these wavelengths, the AOD spectral ratio remained unchanged between the two profiles [around 1.9, as in Eck et al. (2003)]. Between 380 and $440 \mathrm{~nm}$, the $\mathrm{AE}$ was higher over land (around 1.8 at $3 \mathrm{~km}$ ) than over sea (around 0.9 at $3 \mathrm{~km}$ ). A significant reduction of the organic fraction with respect to black carbon in the BBA composition during transport is necessary to explain this behavior. Further analysis will deepen this intriguing result that points to one of the open questions of SAFARI 2000 concerning the evolution of the chemical composition and the optical properties of BBA during transport (Formenti et al. 2003; Haywood et al. 2003; Kirchstetter et al. 2003; Abel et al. 2003).

Figure 8 shows an insight into total and polarized radiances provided by the Observing System Including Polarization in the Solar Infrared Spectrum (OSIRIS) instrument in the visible and near-infrared spectral bands (Table ES3). The situation corresponds to a scene with absorbing aerosols transported above bright homogeneous Sc clouds (Fig. 8a). Absorbing aerosols above clouds change the polarization reflected by the liquid water clouds (Fig. 8b). The peak of polarization centered around $140^{\circ}$ in scattering angle (black solid) corresponds to the primary cloud bow (i.e., the circular structure observed in Fig. 8b). This is a polarized feature of liquid water clouds, which typically exhibits a small spectral dependence. Due to the presence of absorbing aerosols above clouds, the magnitude of the primary cloud bow was significantly reduced and shows an unusual brown color. The algorithm of Peers et al. (2015) has been applied to these remote sensing observations to estimate the key parameters [AOD, SSA, and cloud optical depth (COD), required to compute the aerosol DRE]. Figure $8 c$ shows an example of the OSIRIS retrievals 
a)

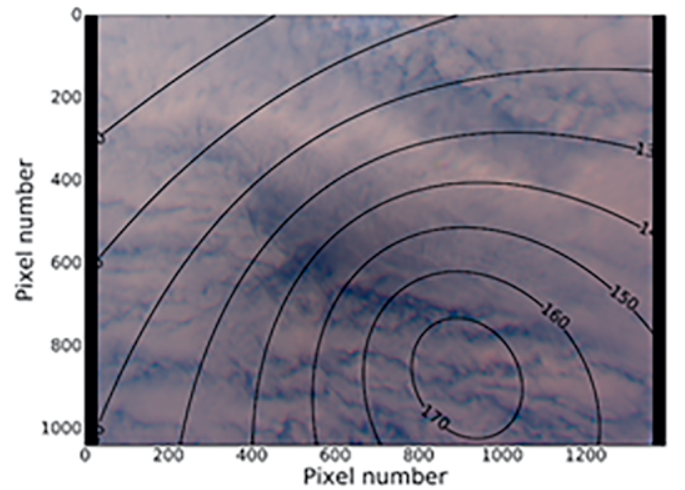

b)

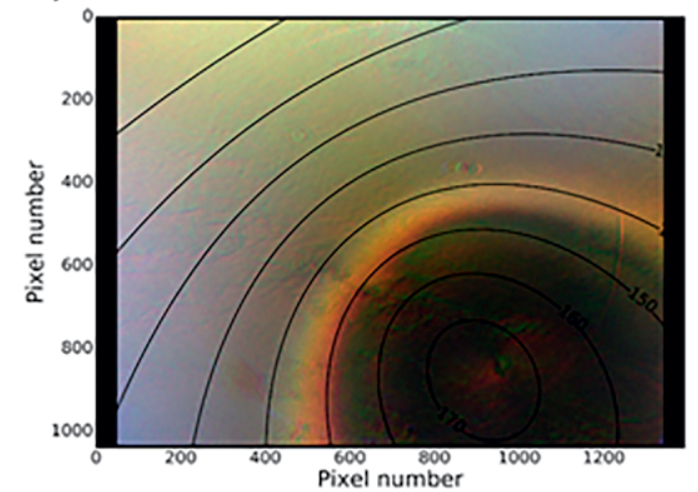

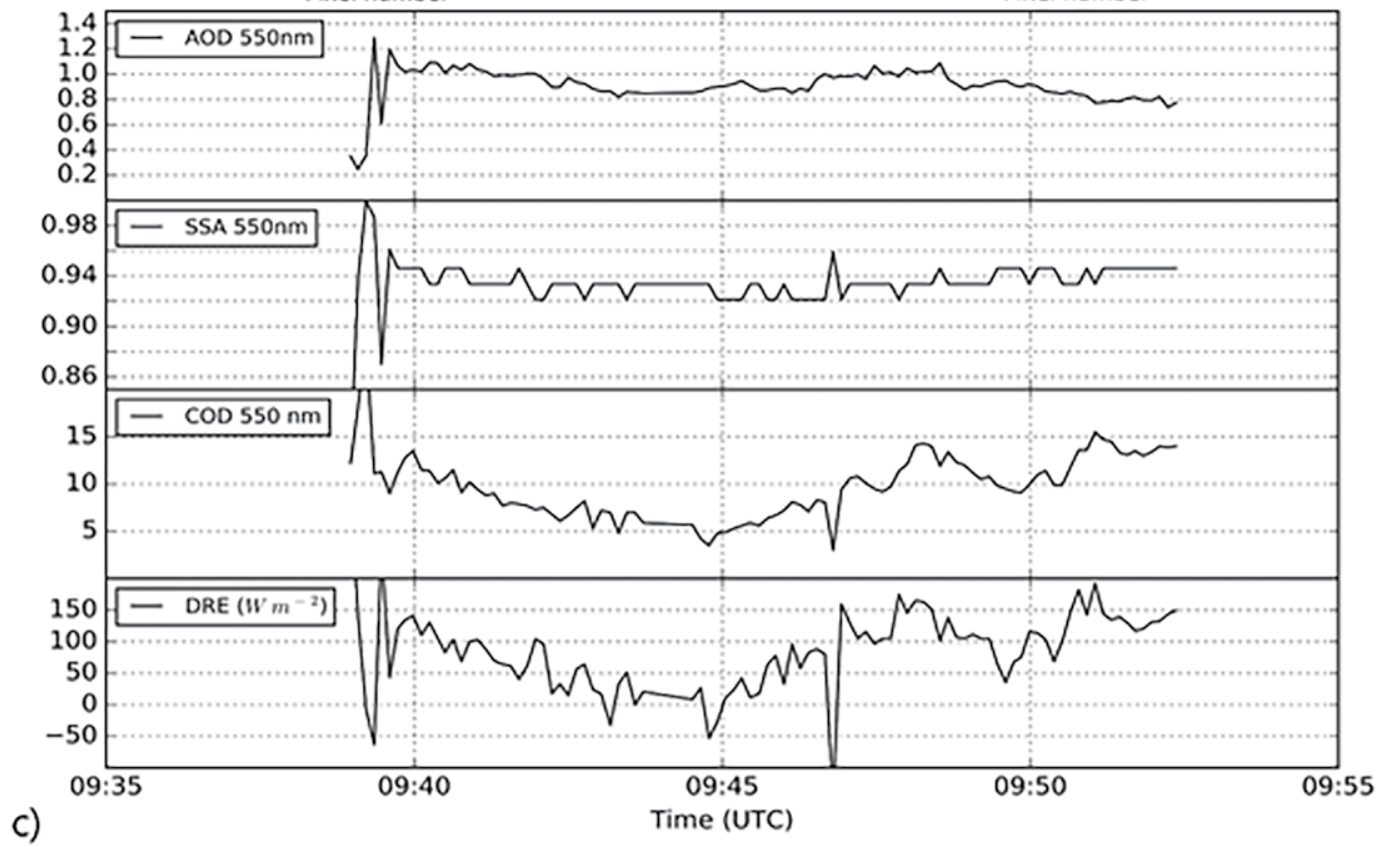

FIG. 8. Composite images illustrating OSIRIS measurements acquired in (a) total and (b) polarized radiances. Circles represent isocontours of scattering angles with a $10^{\circ}$ step. The measurements were acquired during a flight performed at 0940 UTC 5 Sep. Images are produced using a combination of the OSIRIS spectral bands centered on 490, 670, and $865 \mathrm{~nm}$. (c) Example of OSIRIS retrievals performed for a portion of the same flight for (from top to bottom) the AOD at $550 \mathrm{~nm}$, the aerosol single-scattering albedo (SSA) at $865 \mathrm{~nm}$, the cloud optical thickness (COT) at $550 \mathrm{~nm}$, and the resulting DRE of aerosols above clouds $\left(\mathrm{W} \mathrm{m}^{-2}\right)$.

for a portion of flight 6 (5 September 2017), when a large amount of BBA was also transported above clouds (AOD of 0.9 at $550 \mathrm{~nm}$ ). These particles are significantly absorbing and exhibit an SSA of 0.90 at $865 \mathrm{~nm}$. The cloud layer below was optically thick $(5<\mathrm{COD}<150)$. The DRE reached instantaneous values as large as $+100 \mathrm{~W} \mathrm{~m}^{-2}$, consistent with Peers et al. (2015). Further efforts will focus on the retrieval of cloud microphysical properties (effective radius and variance) and aerosol spectral absorption using other available remote sensing observations acquired in the UV and in the middle infrared (Table ES3).

The case studies presented here indicate that the AEROCLO-sA dataset is valuable for evaluating the
BBA parameterizations of regional climate models. For example, Fig. 9 shows a first evaluation of the ALADIN-Climate model using AEROCLO-sA aircraft remote sensing data collected on flight 15 (0800 UTC) near the Namibian coast. The vertical profiles of aerosol extinction coefficient simulated by the ALADIN-Climate model at 440,550, and $1,064 \mathrm{~nm}$ are compared to the extinction coefficient profile retrieved by the LNG lidar at $1,064 \mathrm{~nm}$. The model captures well the aerosol vertical profile of extinction in terms of vertical mixing. The top height of the BBA plume $(\sim 5.5 \mathrm{~km})$ is also well represented. However, the amplitude of the BBA extinction (at $1,064 \mathrm{~nm}$ ) is underestimated by about $0.01 \mathrm{~km}^{-1}$ 

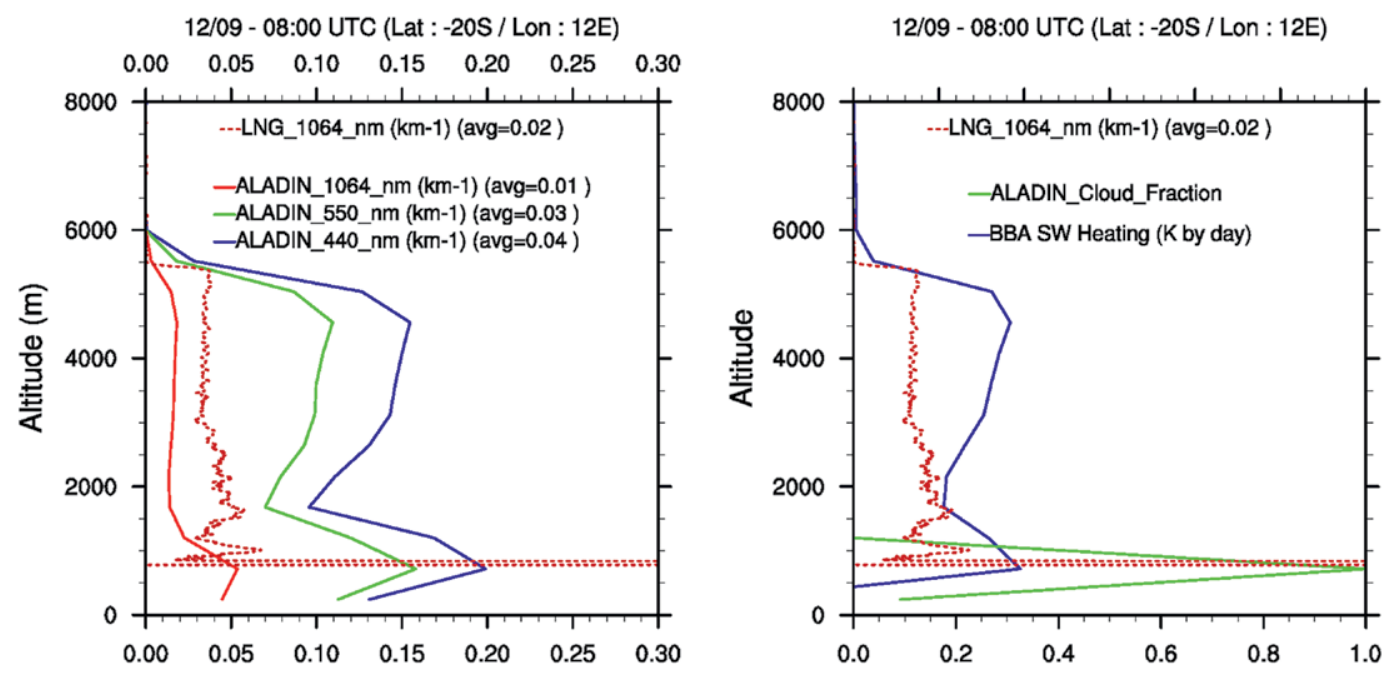

Fig. 9. (left) Comparison of ALADIN-Climate model-derived extinction coefficient profile at I,064 $\mathrm{nm}$ (solid red line) with its LNG counterpart (dashed red line) at 0800 UTC 12 Sep 2017 at a location near the Namibian coast $\left(20^{\circ} \mathrm{S}, 12^{\circ} \mathrm{E}\right)$. Also shown are the ALADIN-derived extinction coefficient profiles at 550 (green solid line) and $355 \mathrm{~nm}$ (blue solid line). (right) LNG-derived extinction coefficient profiles (dashed red line) together with ALADIN-derived cloud fraction (green solid line) and shortwave heating rate associated with the presence of BBA (blue solid line). The profiles are taken in the same location as in the left panel.

$\left(10 \mathrm{Mm}^{-1}\right)$ compared to LNG data. The top of the Sc clouds, observed at about $\sim 800 \mathrm{~m}$ by the LNG lidar, is overestimated (by about $\sim 200 \mathrm{~m}$ ) by ALADINClimate (Fig. 9, right panel). The ALADIN-Climate model indicates a simulated radiative heating of 0.2-0.3 $\mathrm{K} \mathrm{day}^{-1}$ within the BBA plume (Fig. 9, right panel), in agreement with the value recently proposed $\left(+0.33 \mathrm{~K} \mathrm{day}^{-1}\right)$ by Gordon et al. (2018).

Finally, a first estimate of the monthly mean (September 2017) DRE in the visible spectral range and for all-sky conditions exerted by BBA at the TOA is provided in Fig. 10. There is a significant regional

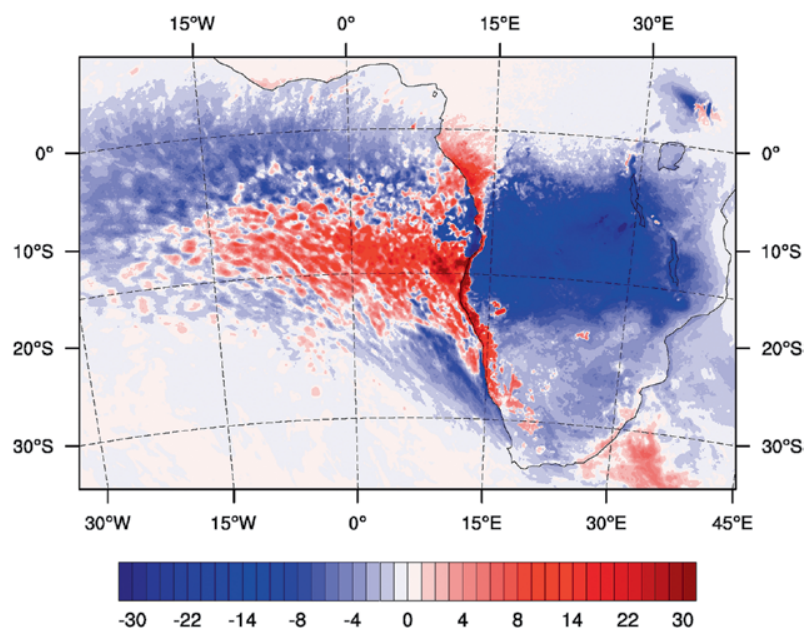

FIG. I0. ALADIN-Climate-derived monthly mean (Sep 2017) shortwave direct radiative effect $\left(W \mathrm{~m}^{-2}\right)$ exerted by smoke particles at the top of the atmosphere (all-sky conditions). gradient in the sign of DRE, with a negative forcing over the continent (net cooling) and positive (net heating) over the southeast Atlantic. Over the ocean, the calculated DRE is found to be in agreement with the literature over this region (Meyer et al. 2013; Feng and Christopher 2015). In addition, positive values are also identified along the Namibian coast, certainly due to the presence of BBA and low Sc clouds. This is consistent with the positive values of the DRE measured by OSIRIS (Fig. 8c).

\section{THE MARINE BOUNDARY LAYER AS A SOURCE OF MARINE AEROSOLS AND CLOUD CONDENSATION NUCLEI.}

AEROCLO-sA also studies the chemical composition of the marine aerosols and its impact on radiation and cloud microphysics. To the best of our knowledge, there is no study in the area since the early paper by Andreae et al. (1995), linking the oxidation of the marine DMS to new sulfate aerosols in the accumulation mode and to new cloud condensation nuclei (CCN) for the Sc [the Charlson-Lovelock-Andreae-Warren (CLAW) hypothesis; Charlson et al. 1987].

Numerous new particle formation events were observed during the field campaign in connection with marine biogenic emissions. An example is shown in Fig. 11 for the early afternoon on 9 September 2017, when a strong increase in the particle number concentration was observed in the diameter ranges of 20-40 and $60-90 \mathrm{~nm}$ (less pronounced). This event is associated with an increase in the $\mathrm{CH}_{3} \mathrm{SO}_{2}^{+}$fragment [linked 


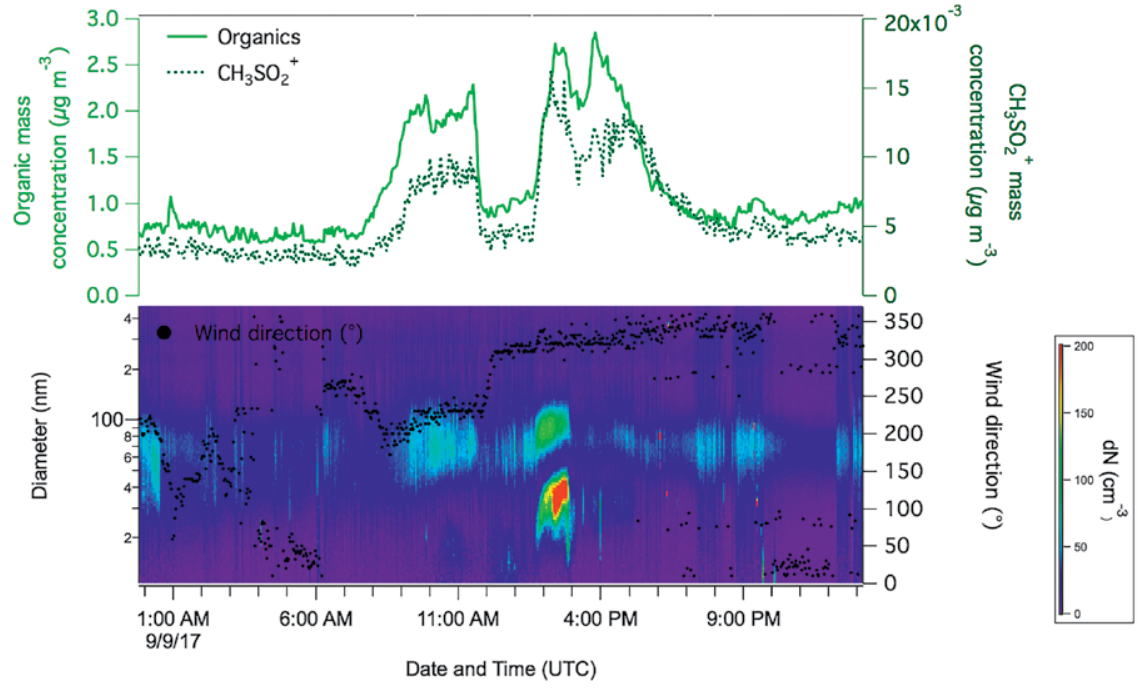

FIG. II. Selected time series during the new particle formation event observed on 9 Sep 2017 at Henties Bay. (top) Time series of the organic mass concentrations (green solid line) and the $\mathrm{CH}_{3} \mathrm{SO}_{2}^{+}$fragment (dashed black line; representative of methanesulfonic acid) measured by the c-ToF-AMS. (bottom) Concurrent number size distribution measured by the SMPS. The $z$ axis represents the total particle number concentration within the measured diameter (left axis) bin. Wind direction (black dots) is displayed on the right axis.

to methanesulfonic acid (MSA)] and the total organic concentrations measured by the compact time-offlight aerosol mass spectrometer (c-ToF-AMS) in particles larger than $100 \mathrm{~nm}$ in diameter. Other observations corroborate the marine biogenic origin for these newly formed particles. First, measurements of the hygroscopic growth factor of the $50-\mathrm{nm}$ particles remained below 1.6 at $85 \% \mathrm{RH}$, suggesting an internally mixed sulfate-organic species. Second, the proton transfer reaction time-of-flight mass spectrometer (PTR-ToF-MS) measured enhanced concentrations of DMS, dimethyl disulfide (DMDS), and diethyl sulfide (DES), and slight increases in other gaseous species (isoprene, acetone, and shortchain aldehydes, alcohols, and carboxylic acids), also observed when taking direct measurements over the sea foam collected along the coast. Finally, data from the SP2 instrument do not show any significant increase in black carbon concentrations, ruling out the possibility of an anthropogenic source for the event. This is also the case for the entire field campaign, suggesting that the anthropogenic contribution during AEROCLO-sA was not significant.

Continuous filter sampling of the aerosol composition of the total and the submicron fractions of the aerosols was performed at Henties Bay during the field campaign (Table ES1). Figure 12 shows the time series of mass concentrations of three water-soluble ions obtained by the analysis of the filters by ion chromatography (IC), as in Desboeufs et al. (2010). We show $\mathrm{Cl}^{-}$as a major component of sea salt, MSA as the oxidation product of marine biogenic $\mathrm{SO}_{2}$, and sulfate $\left(\mathrm{SO}_{4}^{2-}\right)$ and its nonsea-salt fraction ( $\mathrm{nssSO}_{4}^{2-}$ ); $\mathrm{nssSO}_{4}^{2-}$, calculated assuming the mass fraction of 0.14 to $\mathrm{Cl}^{-}$as in seawater (Seinfeld and Pandis 2006), is a tracer of anthropogenic aerosols but can also result from the DMS oxidation chain. There was a significant temporal variability in these measurements during the field campaign and, in particular in those of total $\mathrm{Cl}^{-}$, which exceeded $40 \mu \mathrm{g} \mathrm{m}^{-3}$ on a number of cases. We observe that the $\mathrm{Cl}^{-}$concentrations are mostly determined by the wind direction relative to the coast and secondarily by the wind speed and that the temporal variability of total $\mathrm{SO}_{4}^{2-}$ is closely associated to that of $\mathrm{Cl}^{-}$. Total $\mathrm{SO}_{4}^{2-}$ concentrations were almost always greater than $5 \mu \mathrm{g} \mathrm{m}^{-3}$ and reached $20 \mu \mathrm{g} \mathrm{m}^{-3}$ toward the end of the campaign. The concentrations for both $\mathrm{Cl}^{-}$and $\mathrm{SO}_{4}^{2-}$ were both lower in the submicron fraction $\left(<2.5 \mu \mathrm{g} \mathrm{m}^{-3}\right)$. The comparison of the measured $\mathrm{SO}_{4}^{2-}$ and the calculated $\mathrm{nsSO}_{4}^{2-}$ indicates that the contribution of sea salt to the $\mathrm{SO}_{4}^{2-}$ load is negligible in the fine fraction. In the total fraction, it represents an average of $40 \%$ $( \pm 13 \%)$ of the measured concentrations, and up to $5 \mu \mathrm{g} \mathrm{m}^{-3}$. The total MSA concentrations ranged between 0.04 and $0.1 \mu \mathrm{g} \mathrm{m}^{-3}$, roughly twice than in the fine fraction. This suggests that, on average, the MSA and the $\mathrm{nssSO}_{4}^{2-}$ mass concentrations are distributed almost equally between the fine and the coarse fractions and that the large uptake surface provided by the sea salt particles reduces the potential of new particle formation from marine biogenic sulfur species. The average ratio $\mathrm{MSA} /\left(\mathrm{MSA}+\mathrm{nssSO}_{4}^{2-}\right)$, an indicator of the relative importance of the oxidation pathway of atmospheric DMS to sulfur aerosol particles, was $0.05( \pm 0.01)$ in the submicron fraction and 0.03 $( \pm 0.02)$ in the total aerosol. The fine fraction value is consistent with that found by Andreae et al. (1995). On the contrary, the value for the total aerosols is 

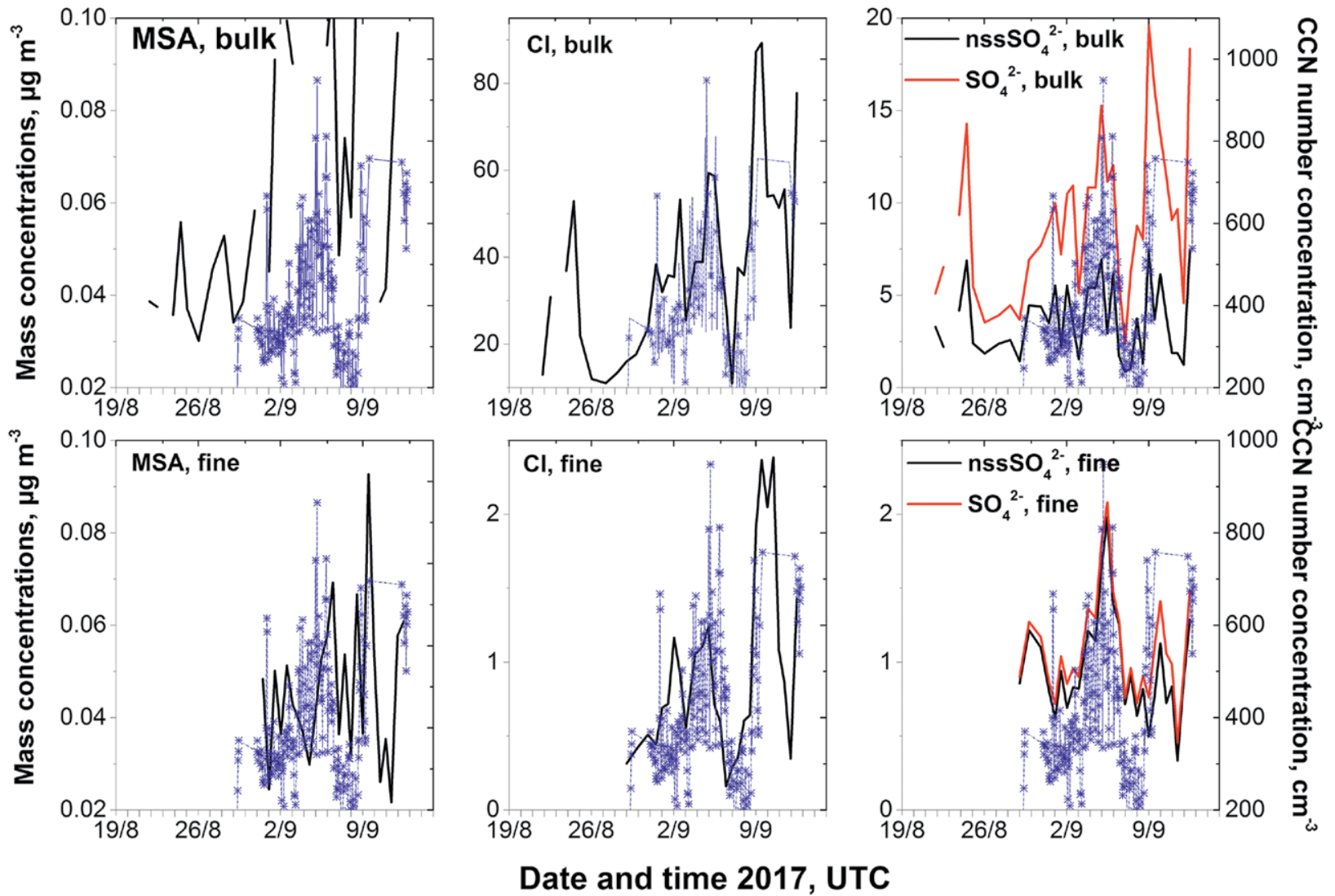

\section{Date and time 2017, UTC}

FIG. I2. Time series of mass concentrations of (left) $\mathrm{MSA}$, (center) $\mathrm{Cl}^{-}$, and (right) $\mathrm{SO}_{4}^{2-}$ (red line) and its nssSO ${ }_{4}^{2-}$ measured at Henties Bay during the field campaign. The total CCN number concentrations measured concurrently is represented by the dotted light blue line. (top) Mass concentrations for the bulk aerosols. (bottom) Mass concentrations in the submicron fraction.

half than previously reported, likely because our total mass includes a significant fraction of particles larger than $10 \mu \mathrm{m}$ in diameter, possibly larger than in the measurements by Andreae et al. (1995). This fraction seems to act as a sink for nssSO ${ }_{4}^{2-}$ more than for MSA. The alkalinity flux from the ocean surface is particularly high in regions of high oceanic productivity (Sievering et al. 2004), such as the nBUS. The alkalinity in sea salt aerosol is known to increase the presence of sulfate in sea-salt particles from DMS oxidation (Alexander et al. 2005) and could explain the preferential uptake of $\mathrm{nsSO}_{4}^{2-}$ on coarse particles in comparison to MSA.

Figure 12 superimposes the 1-h average time series of total $\mathrm{CCN}$ concentrations measured at $0.3 \%$ supersaturation. There is a rough coincidence with the time variability of the inorganic marine aerosol concentrations, as expected in this marine environment (Ayers and Gras 1991; Gras and Keywood 2017). The campaign average for CCN concentrations is $392 \pm 160 \mathrm{~cm}^{-3}$, significantly higher than the range of concentrations $\left(40-300 \mathrm{~cm}^{-3}\right)$ reported by Andreae et al. (1995). However, our campaign average for the
$\mathrm{CCN} / \mathrm{CN}$ ratio $(0.40 \pm 0.17)$ is very comparable to theirs $(0.47 \pm 0.11)$, suggesting that the differences in intensity do not affect the production rate of $\mathrm{CCN}$ active particles which instead seems to be driven by the dominant combination of sea salt and marine nss-sulphur.

The campaign observations on sulfate chemistry presented in Fig. 12 are further confirmed by comparing the campaign values to the 2-yr records of concentrations measured in 2016 and 2017 at HBAO. Figure 13 shows the box-and-whisker plots for the MSA and $\mathrm{nsSO}_{4}^{2-}$ mass concentrations, and the MSA/ $\left(\mathrm{MSA}+\mathrm{nssSO}_{4}^{2-}\right)$, all measured in the mass fraction of particles smaller than $10 \mu \mathrm{m}$ in diameter $\left(\mathrm{PM}_{10}\right)$, and compared to the campaign values in the fine (bold gray) and total fractions (thick red). The campaign values of both the fine and the total MSA are consistent with the long $\mathrm{PM}_{10}$ record, suggesting that there is no significant deposition of MSA on particles larger than $10 \mu \mathrm{m}$. This is not the case of $\mathrm{nssSO}_{4}^{2-}$ as the campaign total concentrations are higher than the concurrent measurements during August-September 2017, and of the long-term average. Figure 13 shows 

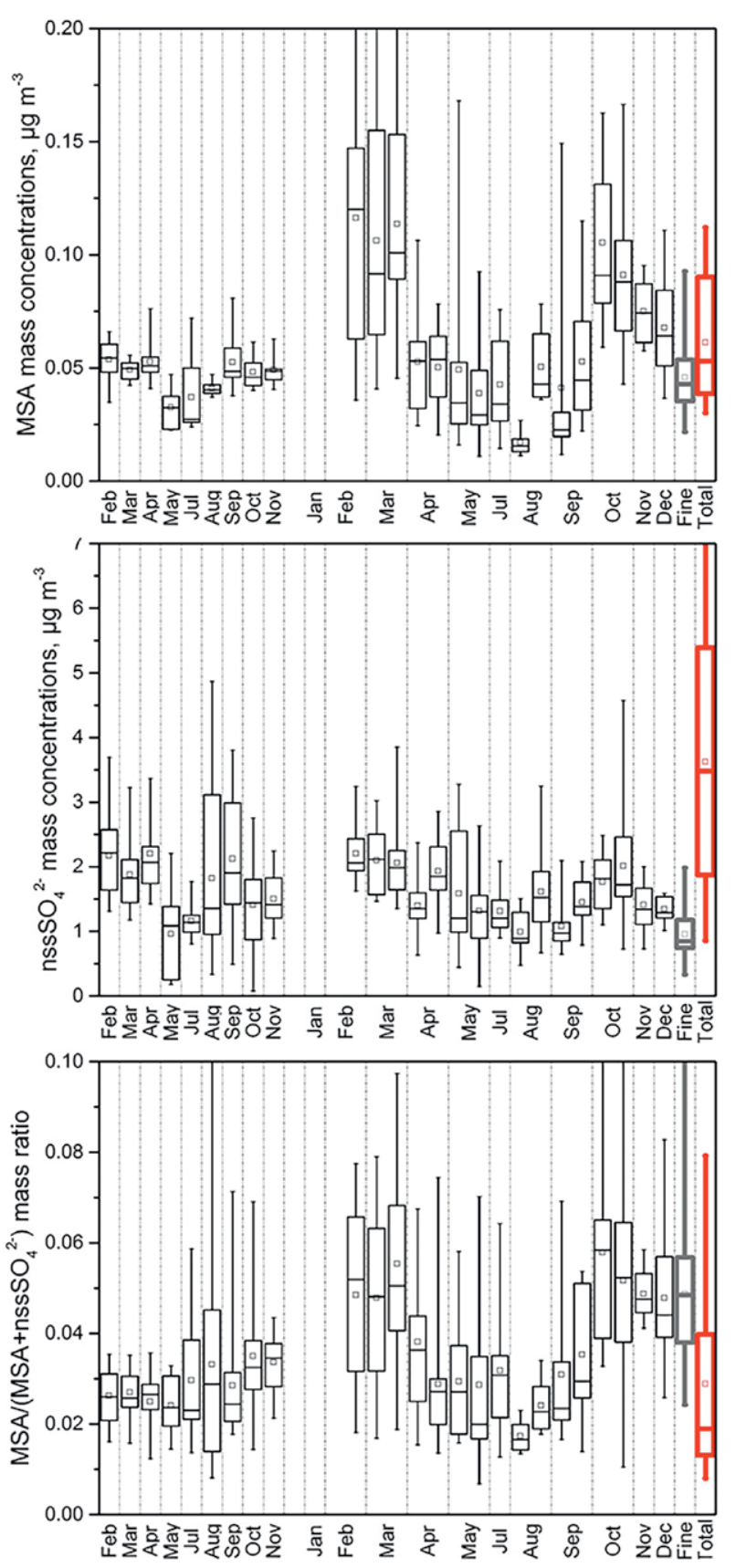

FIG. I3. Box-and-whisker plots for the time series of (top) MSA mass concentrations, (middle) nssSO ${ }_{4}^{2-}$ mass concentrations, and (bottom) $\mathrm{MSA} /\left(\mathrm{MSA}+\mathrm{nssSO}_{4}^{2-}\right)$ measured in 2016 and 2017 in the mass fraction of particles smaller than $10 \mu \mathrm{m}$ in diameter $\left(\mathrm{PM}_{10}\right)$ at the HBAO observatory (black). Values obtained during the AEROCLO-sA field campaign in the submicron mass fraction (gray box) and in the total particular matter fraction (red box) are also shown in the rightmost part of each panel. also a significant seasonal variability, with the main peak season between late austral summer and early austral autumn. These observations are in line with atmospheric observations in the Southern Hemisphere (Ayers et al. 1986) and of those of the ocean sulfur plume activity by Ohde and Dadou (2018). They are, however, inconsistent with the long-term record of chlorophyll $a$, a spaceborne proxy for the blooms of phytoplankton (Louw et al. 2016), peaking in the austral winter (August), early summer (December), and late summer/autumn (April). This highlights the complexity of the links between ocean and air chemistry in the nBUS, and to the many additional factors affecting the production of sulfate aerosols from marine emission. To the best of our knowledge, these are the first long-term and intensive data of marine biogenic sulfur aerosols in this region.

\section{FIRST OBSERVATIONS OF THE MICRO- PHYSICS OF THE COASTAL FOG. The un-} derstanding of the mechanisms of the fog formation (subsidence of low-level cloud base touching the land, radiative evaporation), while under debate, is of crucial importance for future water resources in the Namibian region (Cermak 2012; Eckardt et al. 2013). During the field campaign, we observed several fog events, including major occurrences of a reduction of visibility to less than $1 \mathrm{~km}$ for several hours. We monitored the droplet and the aerosol size distributions, as well as chemical composition during these events, which will be a key element in attributing the mechanism of formation of fog in this region. Figure 14 shows examples of 20-min average number size distribution measured by a Welas 2000 (dashed line) and a Fog-Monitor FM100 (solid line) over diameter range of $0.8-10$ and $4-50 \mu \mathrm{m}$, respectively, for sea spray, mist, and fog with visibility of about $10,2,0.1$, and $0.2 \mathrm{~km}$, respectively. The resultant fog size distributions are very broad compared to the typical narrow modal shape of aircraft data collected in Sc clouds (Brenguier et al. 2011) and are similar to those sampled in continental fogs (Mazoyer et al. 2016) but with a mode of very large droplets around 25-30 $\mu \mathrm{m}$. With typical values of total droplet number concentration up to $100-150 \mathrm{~cm}^{-3}$, the liquid water content reached values as high as $0.2 \mathrm{~g} \mathrm{~m}^{-3}$. These result suggest that the fog events originate from the advection of cloudy air, in agreement with most observations in the area (e.g., Andersen and Cermak 2018), rather than from radiative processes. The cross-linked analysis of the chemical samples collected during the event will shed additional light on these mechanisms. 


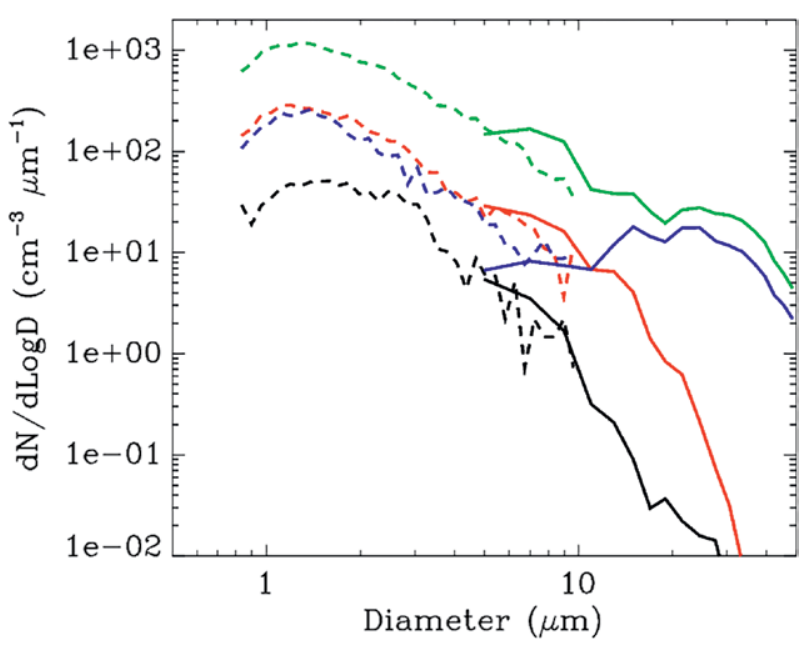

FIG. 14. The 20-min-averaged number size distribution measured by a Welas 2000 (dashed line) and a FogMonitor FMIOO (solid line) over diameter ranges of 0.8- 10 and 4-50 $\mu \mathrm{m}$, respectively, for sea spray (black), mist (red), and fog (green and blue) with visibility of about I0, 2, 0.I, and $0.2 \mathrm{~km}$, respectively.

SUMMARY AND OUTLOOK. The west coast of southern Africa is a true natural laboratory that we can use to investigate the interactions of atmospheric aerosols with radiation and clouds. It is a remote arid region with a low population density, albeit with some intensive anthropogenic activities such as commercial shipping, fishing, and mining. Along with a persistent Sc cloud deck, it is affected by the frequent emission of mineral dust and dense plumes of seasonal transported BBA. The upwelling system of the Benguela current also gives rise to continuous and widespread eruptions of algae-emitting sulfurand organic-rich matter.

State-of-the-art climate predictions indicate that the region should experience warmer weather in the future, affecting both the Sc clouds and regional water resources. These features are important for the regional ecosystem, and also regulate the hemispherical asymmetry in the energy balance, ultimately influencing the position of the ITCZ, and some climate systems such as the West African monsoon (Jones and Haywood 2012). The representation of aerosol perturbations on the regional radiation budget in climate models is therefore an urgent issue to address.

AEROCLO-sA is a large project based on a field campaign in Namibia during August and September 2017, including an aircraft and a ground-based deployment with a total of 30 aircraft flight hours, $500 \mathrm{~h}$ of ground-based data, and 59 vertical sounding by drop- and radiosondes. This campaign supports long-term ground-based observations at the $\mathrm{HBAO}$ observatory operated since 2011.
The first results of the field campaign, described in this paper, are intriguing and highlight the richness of the dataset. To the best of our knowledge, AEROCLO-sA has some "firsts" for southern Africa region that, complementary to other results, will serve to improve our understanding of the austral atmospheric system: the first measurements of the aerosol hygroscopic properties and CCN activity of marine aerosols; the first long-term dataset of non-sea-salt sulfate and MSA concentrations; the first multimodel climatology of dust emissions in the region, including the Etosha Pan and coastal sources; the first observations of the microphysics of coastal fog; and the first combined active and passive remote sensing observations of Sc clouds, mineral dust, and BBA over land.

AEROCLO-sA has also produced a large novel dataset of aerosol and cloud properties retrieved from multispectral, multidirectional, and polarized remote sensing observations. In conjunction with the analysis of new and historical satellite observations, such as those of Polarization and Directionality of the Earth's Reflectances 3 (POLDER-3; Waquet et al. 2013), the new AEROCLO-sA dataset will support the current advanced multispectral retrieval algorithms in preparation by CNES for the MetOp-SG platform, and will serve to evaluate RCM simulations over different time scales.

AEROCLO-sA, together with Observations of Aerosols above Clouds and Their Interactions (ORACLES), Clouds and Aerosol Radiative Impacts and Forcing: Year 2017 (CLARIFY), Layered Atlantic Smoke Interactions with Clouds (LASIC), and Namib Fog Life Cycle Analysis (NaFoLiCa), provide the most extensive measurement effort in the broader southern Atlantic region since SAFARI 2000. These projects each have specific and individual goals, and were implemented independently without overarching coordination prior to or during the field campaigns. They are nonetheless scientifically complementary in providing a large-scale picture of the aerosols and their interactions with clouds and fog, and specifically of the BBA plumes at or near emission (AEROCLO-sA and NaFoLiCa), to short- to midrange transport (AEROCLO-sA and ORACLES), to long-range transport (ORACLES, CLARIFY, and LASIC). AEROCLO-sA now pursues, to the best of its ability, the synergistic analysis of the results by promoting joint data workshops and meetings at international conferences. These initiatives are also important for ensuring dissemination and use by the larger international research community.

Combined, this comprehensive and modern set of observations should allow us, as an international 
community, to address uncertainties outlined by the Intergovernmental Panel on Climate Change (IPCC) and to achieve new and improved multiyear simulations of the effect of aerosols on the regional radiative budget, and the evaluation of future climate.

DATA AVAILABILITY AND DISSEMINATION. AEROCLO-sA has an open data policy. The AEROCLO-sA database is hosted in the Base Afrique de l'Ouest beyond African Monsoon Multidisciplinary Analyses (AMMA) Base (BAOBAB) by the French national atmospheric database AERIS (www.aeris-data.fr/). The BAOBAB portal gathers various major field campaigns and long-term data series in western Africa, including AMMA (Redelsperger et al. 2006) and Dynamics-Aerosol-Chemistry-Cloud Interactions in West Africa (DACCIWA; Flamant et al. 2018). The AEROCLO-sA dataset will be publicly released in October 2019. Meanwhile, data are made available for collaborations by e-mail request to the project scientific steering committee (aeroclo-sc@lisa.u-pec.fr).

Collaborative efforts between AEROCLO-sA, ORACLES, CLARIFY, LASIC, and NaFoLiCa are disseminated through a joint dedicated special issue on open-access Atmospheric Chemistry and Physics and Atmospheric Measurement Techniques journals, initiated in 2018 (www.atmos-chem-phys.net/special _issue978.html).

ACKNOWLEDGMENTS. This work was supported by the French National Research Agency under Grant Agreement ANR-15-CE01-0014-01, the French national program LEFE/INSU, the Programme National de Télédetection Spatiale (PNTS; www.insu.cnrs.fr/pnts), Grant PNTS-2016-14, the French National Agency for Space Studies (CNES), and the South African National Research Foundation (NRF) under Grant UID 105958. The research leading to these results has received funding from the EU's Seventh Framework Programme (FP7/2014-2018) under EUFAR2 Contract 312609. Airborne data were obtained using the aircraft managed by SAFIRE, the French facility for airborne research, an infrastructure of the French CNRS, Météo-France, and the CNES.

The HBAO observatory receives funding through the "Atmospheric Research in Southern Africa and the Indian Ocean" (ARSAIO) project (CNRS and South African NRF), the PICS Contract 260888 (CNRS), as well as by PHC PROTEA of the French Ministery of Foreigns Affairs and International Development (Contracts 33913SF and 38255ZE).

The strong diplomatic assistance of the French Embassy in Namibia, the administrative support of the Service Partnership and Valorisation of the Regional Delegation of the Paris-Villejuif region of the CNRS, and the cooperation of the Namibian National Commission on Research, Science and Technology (NCRST) were invaluable to make the project happen.

The long-term hosting and support of the SANUMARC, a research center of the University of Namibia in Henties Bay, have been essential through the years and are warmly appreciated. The support of the aviation authorities is acknowledged.

The AEROCLO-sA project would have not been successful without the endless efforts of all the research scientists and engineers involved in its preparation, often behind the scenes. They are listed in Table ES1. Their support and enthusiasm are sincerely appreciated.

\section{REFERENCES}

Abel, S. J., J. M. Haywood, E. J. Highwood, J. Li, and P. R. Buseck, 2003: Evolution of biomass burning aerosol properties from an agricultural fire in southern Africa. Geophys. Res. Lett., 30, 1783, https://doi .org/10.1029/2003GL017342.

Adebiyi, A., and P. Zuidema, 2016: The role of the southern African easterly jet in modifying the southeast Atlantic aerosol and cloud environments. Quart. J. Roy. Meteor. Soc., 142, 1574-1589, https://doi .org/10.1002/qj.2765.

Alexander, B., R. J. Park, D. J. Jacob, Q. B. Li, R. M. Yantosca, J. Savarino, C. C. W. Lee, and M. H. Thiemens, 2005: Sulfate formation in sea-salt aerosols: Constraints from oxygen isotopes. J. Geophys. Res., 110, D10307, https://doi.org/10.1029/2004JD005659.

Andersen, H., and J. Cermak, 2018: First fully diurnal fog and low cloud satellite detection reveals life cycle in the Namib. Atmos. Meas. Tech., 11, 5461-5470, https://doi.org/10.5194/amt-11-5461-2018.

Andreae, M. O., and A. Gelencsér, 2006: Black carbon or brown carbon? The nature of light-absorbing carbonaceous aerosols. Atmos. Chem. Phys., 6, 3131-3148, https://doi.org/10.5194/acp-6-3131-2006.

—, W. Elbert, and S. J. de Mora, 1995: Biogenic sulfur emissions and aerosols over the tropical South Atlantic: Atmospheric dimethylsulfide, aerosols and cloud condensation nuclei. J. Geophys. Res., 100, 11335-11 356, https://doi.org/10.1029/94JD02828.

_- J. Fishman, and J. Lindesay, 1996: The Southern Tropical Atlantic Region Experiment (STARE): Transport and Atmospheric Chemistry near the Equator-Atlantic (TRACE A) and Southern African Fire-Atmosphere Research Initiative (SAFARI): An introduction. J. Geophys. Res., 101, 23 519-23520, https://doi.org/10.1029/96JD01786.

Ayers, G. P., and J. L. Gras, 1991: Seasonal relationship between cloud condensation nuclei and aerosol 
methanesulphonate in marine air. Nature, 353, 834-835, https://doi.org/10.1038/353834a0.

— J. P. Ivey, and H. S. Goodman, 1986: Sulfate and methanesulphonate in the maritime aerosol at Cape Grim, Tasmania. J. Atmos. Chem., 4, 173-185, https:// doi.org/10.1007/BF00053777.

Bakun, A., D. B. Field, A. Redondo-Rodriguez, and S. J. Weeks, 2010: Greenhouse gas, upwelling-favorable winds, and the future of coastal ocean upwelling ecosystems. Global Change Biol., 16, 1213-1228, https:// doi.org/10.1111/j.1365-2486.2009.02094.x.

Bates, T. S., and Coauthors, 2001: Regional physical and chemical properties of the marine boundary layer aerosol across the Atlantic during Aerosols99: An overview. J. Geophys. Res., 106, 20767-20782, https:// doi.org/10.1029/2000JD900578.

Bluvshtein, N., and Coauthors, 2017: Broadband optical properties of biomass-burning aerosol and identification of brown carbon chromophores. J. Geophys. Res. Atmos., 122, 5441-5456, https://doi. org/10.1002/2016JD026230.

Borchers, S. L., B. Schnetger, P. Böning, and H.-J. Brumsack, 2005: Geochemical signatures of the Namibian diatom belt: Perennial upwelling and intermittent anoxia. Geochem. Geophys. Geosyst., 6, Q06006, https://doi.org/10.1029/2004GC000886.

Boucher, O., and Coauthors, 2013: Clouds and aerosols. Climate Change 2013: The Physical Science Basis, T. F. Stocker et al., Eds., Cambridge University Press, 571-657.

Brenguier, J.-L., F. Burnet, and O. Geoffroy, 2011: Cloud optical thickness and liquid water path. Does the $k$ coefficient vary with droplet concentration? Atmos. Chem. Phys., 11, 9771-9786, https://doi.org/10.5194 /acp-11-9771-2011.

Carr, M.-E., 2002: Estimation of potential productivity in eastern boundary currents using remote sensing. Deep-Sea Res. II, 49, 58-80, https://doi.org/10.1016 /S0967-0645(01)00094-7.

Cermak, J., 2012: Low clouds and fog along the southwestern African coast-Satellite-based retrieval and spatial pattern. Atmos. Res., 116, 15-21, https://doi .org/10.1016/j.atmosres.2011.02.012.

Charlson, R. J., J. E. Lovelock, M. O. Andreae, and S. G. Warren, 1987: Oceanic phytoplankton, atmospheric sulphur, cloud albedo and climate. Nature, 326, 655-661, https://doi.org/10.1038/326655a0.

Dansie, A. P., G. F. S. Wiggs, D. S. G. Thomas, and R. Washington, 2017: Measurements of windblown dust characteristics and ocean fertilization potential: The ephemeral river valleys of Namibia. Aeolian Res., 29, 30-41, https://doi.org/10.1016/j .aeolia.2017.08.002.
Das, S., and Coauthors, 2017: Biomass burning aerosol transport and vertical distribution over the South African-Atlantic region. J. Geophys. Res. Atmos., 122, 6391-6415, https://doi.org/10.1002/2016JD026421.

Deboudt, K., P. Flament, M. Choël, A. Gloter, S. Sobanska, and C. Colliex, 2010: Mixing state of aerosols and direct observation of carbonaceous and marine coatings on African dust by individual particle analysis. J. Geophys. Res., 115, D24207, https://doi .org/10.1029/2010JD013921.

Desboeufs, K., E. Journet, J.-L. Rajot, S. Chevaillier, S. Triquet, P. Formenti, and A. Zakou, 2010: Chemistry of rain events in West Africa: Evidence of dust and biogenic influence in convective systems. Atmos. Chem. Phys., 10, 9283-9293, https://doi.org/10.5194 /acp-10-9283-2010.

Eck, T. F., and Coauthors, 2003: Variability of biomass burning aerosol optical characteristics in southern Africa during the SAFARI 2000 dry season campaign and a comparison of single scattering albedo estimates from radiometric measurements. J. Geophys. Res., 108, 8477, https://doi.org/10.1029/2002JD002321.

Eckardt, F. D., and Coauthors, 2013: The nature of moisture at Gobabeb, in the central Namib Desert. J. Arid Environ., 93, 7-19, https://doi.org/10.1016/j .jaridenv.2012.01.011.

Feng, N., and S. A. Christopher, 2015: Measurementbased estimates of direct radiative effects of absorbing aerosols above clouds. J. Geophys. Res. Atmos., 120, 6908-6921, https://doi.org/10.1002/2015JD023252.

Flamant, C., and Coauthors, 2018: The Dynamics-Aerosol-Chemistry-Cloud Interactions in West Africa field campaign: Overview and research highlights. Bull. Amer. Meteor. Soc., 99, 83-104, https://doi .org/10.1175/BAMS-D-16-0256.1.

Flato, G., and Coauthors, 2013: Evaluation of climate models. Climate Change 2013: The Physical Science Basis, T. F. Stocker et al., Eds., Cambridge University Press, 741-866, https://doi.org/10.1017 /CBO9781107415324.020.

Formenti, P., S. J. Piketh, and H. J. Annegarn, 1999: Detection of non-sea salt sulphate aerosol at a remote coastal site in South Africa: A PIXE study. Nucl. Instrum. Methods Phys. Res., 150B, 332-338, https:// doi.org/10.1016/S0168-583X(98)01041-6.

— W. Elbert, W. Maenhaut, J. Haywood, S. Osborne, and M. O. Andreae, 2003: Inorganic and carbonaceous aerosols during the Southern African Regional Science Initiative (SAFARI 2000) experiment: Chemical characteristics, physical properties, and emission data for smoke from African biomass burning. J. Geophys. Res., 108, 8488, https://doi.org /10.1029/2002JD002408. 
_, and Coauthors, 2018: Three years of measurements of light-absorbing aerosols over coastal Namibia: Seasonality, origin, and transport. Atmos. Chem. Phys., 18, 17 003-17 016, https://doi.org/10.5194 /acp-18-17003-2018.

Gainusa-Bogdan, A., F. Hourdin, A. Khadre Traore, and P. Braconnot, 2018: Omens of coupled model biases in the CMIP5 AMIP simulations. Climate Dyn., 51, 2927-2941, https://doi.org/10.1007/s00382 -017-4057-3.

Ginoux, P., J. M. Prospero, T. E. Gill, N. C. Hsu, and M. Zhao, 2012: Global-scale attribution of anthropogenic and natural dust sources and their emission rates based on MODIS Deep Blue aerosol products. Rev. Geophys., 50, RG3005, https://doi .org/10.1029/2012RG000388.

Giorgi, F., and Coauthors, 2012: RegCM4: Model description and preliminary tests over multiple CORDEX domains. Climate Res., 52, 7-29, https:// doi.org/10.3354/cr01018.

Gordon, H., and Coauthors, 2018: Large simulated radiative effects of smoke in the south-east Atlantic. Atmos. Chem. Phys., 18, 15261-15289, https://doi .org/10.5194/acp-18-15261-2018.

Gras, J. L., and M. Keywood, 2017: Cloud condensation nuclei over the Southern Ocean: Wind dependence and seasonal cycles. Atmos. Chem. Phys., 17, 44194432, https://doi.org/10.5194/acp-17-4419-2017.

Haensler, A., J. Cermak, S. Hagemann, and D. Jacob, 2011: Will the southern African west coast fog be affected by future climate change? Results of an initial fog projection using a regional climate model. Erdkunde, 65, 261-275, https://doi.org/10.3112/erdkunde .2011.03.04.

Haywood, J., P. Francis, O. Dubovik, M. Glew, and B. Holben, 2003: Comparison of aerosol size distributions, radiative properties, and optical depths determined by aircraft observations and sun photometers during SAFARI 2000. J. Geophys. Res., 108, 8471, https://doi.org/10.1029/2002JD002687.

Hobbs, P. V., 2003: Clean air slots amid dense atmospheric pollution in southern Africa. J. Geophys. Res., 108, 8490, https://doi.org/10.1029/2002JD002156.

Hourdin, F., A. Găinusă-Bogdan, P. Braconnot, J.-L. Dufresne, A.-K. Traore, and C. Rio, 2015: Air moisture control on ocean surface temperature, hidden key to the warm bias enigma. Geophys. Res. Lett., 42, 10885-10893, https://doi.org/10.1002/2015GL066764.

Intergovernmental Panel on Climate Change, 2013: Annex I: Atlas of global and regional climate projections. Climate Change 2013: The Physical Science Basis, T. F. Stocker et al., Eds., Cambridge University Press, 1311-1393.
Jarre, A., and Coauthors, 2015: Synthesis: Climate effects on biodiversity, abundance and distribution of marine organisms in the Benguela. Fish. Oceanogr., 24, 122-149, https://doi.org/10.1111/fog.12086.

Johansson, L., J.-P. Jalkanen, and J. Kukkonen, 2017: Global assessment of shipping emissions in 2015 on a high spatial and temporal resolution. Atmos. Environ., 167, 403-415, https://doi.org/10.1016/j .atmosenv.2017.08.042.

Jones, A., and J. M. Haywood, 2012: Sea-spray geoengineering in the HadGEM2-ES Earth-system model: Radiative impact and climate response. Atmos. Chem. Phys., 12, 10 887-10 898, https://doi .org/10.5194/acp-12-10887-2012.

,-- , and O. Boucher, 2009: Climate impacts of geoengineering marine stratocumulus clouds. $J$. Geophys. Res., 114, D10106, https://doi.org/10.1029 /2008JD011450.

Keeling, R. F., A. Körtzinger, and N. Gruber, 2010: Ocean deoxygenation in a warming world. Annu. Rev. Mar. Sci., 2, 199-229, https://doi.org/10.1146/annurev .marine.010908.163855.

Keil, A., and J. M. Haywood, 2003: Solar radiative forcing by biomass burning aerosol particles during SAFARI 2000: A case study based on measured aerosol and cloud properties. J. Geophys. Res., 108, 8467, https://doi.org/10.1029/2002JD002315.

Kirchstetter, T. W., T. Novakov, P. V. Hobbs, and B. Magi, 2003: Airborne measurements of carbonaceous aerosols in southern Africa during the dry biomass burning season. J. Geophys. Res., 108, 8476, https:// doi.org/10.1029/2002JD002171.

Lac, C., and Coauthors, 2018: Overview of the Meso-NH model version 5.4 and its applications. Geosci. Model Dev., 11, 1929-1969, https://doi.org/10.5194/gmd-11 -1929-2018.

Leahy, L. V., T. L. Anderson, T. F. Eck, and R. W. Bergstrom, 2007: A synthesis of single scattering albedo of biomass burning aerosol over southern Africa during SAFARI 2000. Geophys. Res. Lett., 34, L12814, https://doi.org/10.1029/2007 GL029697.

Lennard, C. J., G. Nikulin, A. Dosio, and W. MoufoumaOkia, 2018: On the need for regional climate information over Africa under varying levels of global warming. Environ. Res. Lett., 13, 060401, https://doi .org/10.1088/1748-9326/aab2b4.

Lewis, K., W. P. Arnott, H. Moosmüller, and C. E. Wold, 2008: Strong spectral variation of biomass smoke light absorption and single scattering albedo observed with a novel dual-wavelength photoacoustic instrument. J. Geophys. Res., 113, D16203, https://doi .org/10.1029/2007JD009699. 
Lindesay, J. A., M. O. Andreae, J. G. Goldammer, G. Harris, H. J. Annegarn, M. Garstang, R. J. Scholes, and B. W. van Wilgen, 1996: International Geosphere Biosphere Programme/International Global Atmospheric Chemistry SAFARI 92 field experiment: Background and overview. J. Geophys. Res., 101, 23 521-23 530, https://doi.org/10.1029/96JD01512.

Liu, S., and Coauthors, 2014: Aerosol single scattering albedo dependence on biomass combustion efficiency: Laboratory and field studies. Geophys. Res. Lett., 41, 742-748, https://doi.org/10.1002/2013GL058392.

Louw, D., A. Van der Plas, V. Mohrholz, N. Wasmund, T. Junker, and A. Eggert, 2016: Seasonal and interannual phytoplankton dynamics and forcing mechanisms in the northern Benguela upwelling system. J. Mar. Syst., 157, 124-134, https://doi.org/10.1016/j .jmarsys.2016.01.009.

Magi, B. I., P. V. Hobbs, B. Schmid, and J. Redemann, 2003: Vertical profiles of light scattering, light absorption, and single scattering albedo during the dry, biomass burning season in southern Africa and comparisons of in situ and remote sensing measurements of aerosol optical depths. J. Geophys. Res., 108, 8504, https://doi.org/10.1029/2002JD002361.

Maúre, G., I. Pinto, M. Ndebele-Murisa, M. Muthige, C. Lennard, G. Nikulin, A. Dosio, and A. Meque, 2018: The southern African climate under $1.5^{\circ} \mathrm{C}$ and $2^{\circ} \mathrm{C}$ of global warming as simulated by CORDEX regional climate models. Environ. Res. Lett., 13, 065002, https://doi.org/10.1088/1748-9326/aab190.

Mazoyer, M., F. Burnet, G. C. Roberts, M. Haeffelin, J.-C. Dupont, and T. Elias, 2016: Experimental study of the aerosol impact on fog microphysics. Atmos. Chem. Phys. Discuss., https://doi.org/10.5194/acp-2016-103.

Meyer, K., S. Platnick, L. Oreopoulos, and D. Lee, 2013: Estimating the direct radiative effect of absorbing aerosols overlying marine boundary layer clouds in the southeast Atlantic using MODIS and CALIOP. J. Geophys. Res. Atmos., 118, 4801-4815, https://doi .org/10.1002/jgrd.50449.

Myhre, G., and Coauthors, 2013: Radiative forcing of the direct aerosol effect from AeroCom phase II simulations. Atmos. Chem. Phys., 13, 1853-1877, https://doi .org/10.5194/acp-13-1853-2013.

Nabat, P., and Coauthors, 2015: Dust aerosol radiative effects during summer 2012 simulated with a coupled regional aerosol-atmosphere-ocean model over the Mediterranean. Atmos. Chem. Phys., 15, 3303-3326, https://doi.org/10.5194/acp-15-3303-2015.

Ohde, T., and I. Dadou, 2018: Seasonal and annual variability of coastal sulphur plumes in the northern Benguela upwelling system. PLOS ONE, 13, e0192140, https://doi.org/10.1371/journal.pone.0192140.
Olivier, J., 1995: Spatial distribution of fog in the Namib. J. Arid Environ., 29, 129-138, https://doi.org/10.1016 /S0140-1963(05)80084-9.

Peers, F., and Coauthors, 2015: Absorption of aerosols above clouds from POLDER/PARASOL measurements and estimation of their direct radiative effect. Atmos. Chem. Phys., 15, 4179-4196, https://doi.org /10.5194/acp-15-4179-2015.

Piketh, S. J., H. J. Annegarn, and P. D. Tyson, 1999: Lower tropospheric aerosol loadings over South Africa: The relative contribution of aeolian dust, industrial emissions, and biomass burning. J. Geophys. Res., 104, 1597-1607, https://doi.org/10.1029/1998JD100014.

Radney, J. G., R. You, M. R. Zachariah, and C. D. Zangmeister, 2017: Direct in situ mass specific absorption spectra of biomass burning particles generated from smoldering hard and softwoods. Environ. Sci. Technol., 51, 5622-5629, https://doi.org/10.1021 /acs.est.7b00810.

Redelsperger, J.-L., C. D. Thorncroft, A. Diedhiou, T. Lebel, D. J. Parker, and J. Polcher, 2006: African Monsoon Multidisciplinary Analysis: An international research project and field campaign. Bull. Amer. Meteor. Soc., 87, 1739-1746, https://doi.org/10.1175 /BAMS-87-12-1739.

Roehrig, R., D. Bouniol, F. Guichard, F. Hourdin, and J. L. Redelsperger, 2013: The present and future of the West African monsoon: A process-oriented assessment of CMIP5 simulations along the AMMA transect. J. Climate, 26, 6471-6505, https://doi.org /10.1175/JCLI-D-12-00505.1.

Ross, K. E., S. J. Piketh, R. T. Bruintjes, R. P. Burger, R. J. Swap, and H. J. Annegarn, 2003: Spatial and seasonal variations in $\mathrm{CCN}$ distribution and the aerosol-CCN relationship over southern Africa. J. Geophys. Res., 108, 8481, https://doi.org/10.1029/2002JD002384.

Saturno, J., and Coauthors, 2018: Black and brown carbon over central Amazonia: Long-term aerosol measurements at the ATTO site. Atmos. Chem. Phys., 18, 12 817-12 843, https://doi.org/10.5194/acp-18 $-12817-2018$.

Schepanski, K., M. Mallet, B. Heinold, and M. Ulrich, 2016: North African dust transport toward the western Mediterranean Basin: Atmospheric controls on dust source activation and transport pathways during June-July 2013. Atmos. Chem. Phys., 16, $14147-$ 14 168, https://doi.org/10.5194/acp-16-14147-2016.

Seely, M. K., and J. R. Henschel, 1998: The climatology of Namib fog. Proc. First Int. Conf. on Fog, Fog Collection, and Dew, Vancouver, BC, Canada, International Fog and Dew Association, 353-356.

—, M. P. de Vos, and G. N. Louw, 1977: Fog imbibition, satellite fauna and unusual leaf structure in a Namib 
Desert dune plant Trianthema hereroensis. S. Afr. J. Sci., 73, 169-172.

Seinfeld, J. H., and S. N. Pandis, 2006: Atmospheric Chemistry and Physics: From Air Pollution to Climate Change. 2nd ed. Wiley, 1203 pp.

Shannon, L. V., and G. Nelson, 1996: The Benguela: Large scale features and processes and system variability. The South Atlantic, Springer, 163-210, https:// doi.org/10.1007/978-3-642-80353-6_9.

Sievering, H., J. Cainey, M. Harvey, J. McGregor, and S. Nichol, 2004: Aerosol non-sea-salt sulfate in the remote marine boundary layer under clear-sky and normal cloudiness conditions: Ocean-derived biogenic alkalinity enhances sea-salt sulfate production by ozone oxidation. J. Geophys. Res., 109, D19317, https://doi.org/10.1029/2003JD004315.

Swap, R., M. Garstang, S. A. Macko, P. D. Tyson, W. Maenhaut, P. Artaxo, P. Kållberg, and R. Talbot, 1996: The long-range transport of southern African aerosols to the tropical South Atlantic. J. Geophys. Res., 101, 23777-23 791, https://doi.org/10.1029/95JD01049.

— , H. J. Annegarn, J. T. Suttles, M. D. King, S. Platnick, J. L. Privette, and R. J. Scholes, 2003: Africa burning: A thematic analysis of the Southern African Regional Science Initiative (SAFARI 2000). J. Geophys. Res., 108, 8465, https://doi.org/10.1029/2003JD003747.

Tournadre, J., 2014: Anthropogenic pressure on the open ocean: The growth of ship traffic revealed by altimeter data analysis. Geophys. Res. Lett., 41, 7924-7932, https://doi.org/10.1002/2014GL061786.

Tyson, P. D., and R. A. Preston-Whyte, 2000: The Weather and Climate of Southern Africa. Oxford University Press, 396 pp.

van der Werf, G. R., and Coauthors, 2010: Global fire emissions and the contribution of deforestation, savanna, forest, agricultural, and peat fires (19972009). Atmos. Chem. Phys., 10, 11 707-11 735, https:// doi.org/10.5194/acp-10-11707-2010.

Verheye, H. M., T. Lamont, J. A. Huggett, A. Kreiner, and I. Hampton, 2016: Plankton productivity of the Benguela Current Large Marine Ecosystem (BCLME). Environ. Dev., 17 (Suppl.), 75-92, https:// doi.org/10.1016/j.envdev.2015.07.011.

Vickery, K. J., F. D. Eckardt, and R. G. Bryant, 2013: A sub-basin scale dust plume source frequency inventory for southern Africa, 2005-2008. Geophys. Res. Lett., 40, 5274-5279, https://doi.org/10.1002 /grl.50968.

Waquet, F., F. Peers, F. Ducos, P. Goloub, S. Platnick, J. Riedi, D. Tanré, and F. Thieuleux, 2013: Global analysis of aerosol properties above clouds. Geophys. Res. Lett., 40, 5809-5814, https://doi.org/10.1002 /2013GL057482.

Washington, R., and M. Todd, 2005: Atmospheric controls on mineral dust emission from the Bodele Depression, Chad: The role of the low-level jet. Geophys. Res. Lett., 32, L17701, https://doi.org/10.1029 /2005GL023597.

Wasmund, N., H. Siegel, K. Bohata, A. Flohr, A. Hansen, and V. Mohrholz, 2016: Phytoplankton stimulation in frontal regions of Benguela upwelling filaments by internal factors. Front. Mar. Sci., 3, 210, https:// doi.org/10.3389/fmars.2016.00210.

Weeks, S. J., B. Currie, A. Bakun, and K. R. Peard, 2004: Hydrogen sulphide eruptions in the Atlantic Ocean off southern Africa: Implications of a new view based on SeaWiFS satellite imagery. Deep-Sea Res. I, 51, 153-172, https://doi.org/10.1016/j.dsr.2003.10.004.

Zheng, Y., T. Shinoda, J.-L. Lin, and G. N. Kiladis, 2011: Sea surface temperature biases under the stratus cloud deck in the southeast Pacific Ocean in 19 IPCC AR4 coupled general circulation models. J. Climate, 24, 4139-4164, https://doi.org/10.1175 /2011JCLI4172.1.

Zuidema, P., J. Redemann, J. Haywood, R. Wood, S. Piketh, M. Hipondoka, and P. Formenti, 2016: Smoke and clouds above the southeast Atlantic: Upcoming field campaigns probe absorbing aerosol's impact on climate. Bull. Amer. Meteor. Soc., 97, 1131-1135, https://doi.org/10.1175/BAMS-D-15-00082.1. 